\title{
Kadem Kaynaa romanının söz varlığı üzerine bir değerlendirme ${ }^{1}$
}

\section{Ceyda ERDİN ${ }^{2}$}

\section{Levent DOĞAN3}

APA: Erdin, C.; Doğan, L. (2020). Kadem Kaynaa romanının söz varlı̆̆ üzerine bir değerlendirme. RumeliDE Dil ve Edebiyat Araştırmaları Dergisi, (Ö7), 15-38. DOI: 10.2900o/rumelide.808177.

\section{$\ddot{O} \mathbf{z}$}

Dil ve edebiyat arasında öteden beri karşlıklı bir etkileşim söz konusudur. Bir dilin korunarak yaşatılması yanında gelişerek zenginleşmesinde edebiyat ürünleri etkin bir role sahiptir. $\mathrm{Bu}$ bakımdan her toplumda üretilen edebî ürünler o toplumun ve kullanılan dilin hazineleri sayılır. Bu dil hazinelerinin önemli bir işlevi de meydana geldikleri toplum ve yazıldıkları dil hakkında araştırmacıya kılavuzluk etmeleridir. Bilimsel bir bakışla ele alındıkları takdirde dil ve toplumla alakalı farklı alanlara özgü pek çok sorunun cevaplanmasında veya karanlıkta kalmış noktaların aydınlatılmasında yarar sağlarlar. Yok olma tehlikesiyle karşı karşıya olan Gagauzca için şair ve yazarların ana diliyle yarattıkları edebî türden her eser ayrı bir değer taşır. Ancak meydana getirilen bu eserlerin dilsel açıdan işlenmesi de gerekir. Edebî ürünlerin bir dilin söz varlığının ortaya çıkarılmasındaki rolü malumdur. Söz konusu ürünlerin işlenmesiyle kaybolmaya yüz tutan Gagauzcanın söz varlığı kayıt altına alınacağı gibi yazara özgü farklı ve yeni kullanımların da tespit edilerek dile kazandırılması sağlanacaktır. Çalışmamızda bu amaçla çağdaş Gagauz edebiyatının roman türünde son çıkan eseri olan Kadem Kaynaa romanı incelenmiştir. Mariya Mercanka tarafından kaleme alınan bu roman, çalı̧̧mada yazarın söz varlığı, dili ve üslubu açısından değerlendirilmiştir. Çalışma kapsamına romandaki isim ve fiil türünden sözcüklerin on ve üzeri tekrar sayısına sahip olanlar dâhil edilmiştir. Bundan başka yazarın eserdeki atasözü, deyim, ikileme, kalıp söz ve yabancı sözcük kullanımı değerlendirilmiştir. Ayrıca romandan tespit edilen bu söz varlığı unsurlarının Türkiye Türkçesi ve ağızlarıyla ortak olanları belirtilerek bunların bir kısmında görülen farklılıklara değinilmiştir.

Anahtar kelimeler: Çağdaş Gagauz edebiyatı, söz varlı̆̆ı, Gagauz Türkçesi, roman

\section{An evaluation on the vocabulary of Kadem Kaynaa}

\begin{abstract}
There has always been a mutual interaction between language and literature. Literary products have an active role in the preservation, survival and development and enrichment of a language. In this regard, literary products produced in every society are considered as the treasures of that society and the language used. An important function of these language treasures is that they guide the researcher about the society in which they occur and the language in which they are written. If taken from a scientific perspective, they are useful in answering many questions specific to different
\end{abstract}

$1 \quad$ Bu makale, Dr. Öğr. Üyesi Levent Doğan danışmanlığında hazırlanan "Mariya Mercanka’nın Kadem Kaynaa Adlı Romanının Söz Varlığı Bakımından İncelenmesi” başlıklı Yüksek Lisans tezinden üretilmiștir.

2 YL Öğrencisi, Trakya Üniversitesi, Sosyal Bilimler Enstitüsü, Balkan Çalışmaları ABD (Edirne, Türkiye), ceydaerdin@trakya.edu.tr, ORCID ID: oooo-0002-7240-8772 [Makale kaylt tarihi: 13.07.2020-kabul tarihi: 20.10.2020; DOI: $10.29000 /$ rumelide.808177]

3 Dr. Öğr. Üyesi, Trakya Üniversitesi, Edebiyat Fakültesi, Türk Dili ve Edebiyatı Bölümü (Edirne, Türkiye), ldogan@trakya.edu.tr, ORCID ID: 0000-0002-0538-4002 
areas of language and society or in illuminating the dark spots. Every literary genre created by poets and writers in their mother tongue has a different value for the endangered Gagauz Turkish. However, these works must be processed linguistically. The role of literary products in revealing the presence of a language is well known. By processing the products in question, the vocabulary of the endangered Gagauz Turkish will be recorded, as well as different and new uses specific to the author will be identified and will gain to the language. For this purpose in our study the novel of Kadem Kaynaa, which is the latest work of the novel Gagauz literature in the field of novel, was examined. This novel, written by Mariya Mercanka, was evaluated in terms of the author's vocabulary, language and style. Those who have ten or more repetitions of noun and verb type words in the novel are included in the scope of the study. In addition the proverb, idiom, reduplication, formulaic expression and use of foreign words in the novel were evaluated. It is also mentioned words have in common with Turkey Turkish and dialects. The differences seen in some of these words are mentioned.

Keywords: Modern Gagauz literature, vocabulary, Gagauz Turkish, novel

\section{Giriş}

Dünyanın farklı coğrafyalarında varlığını sürdüren Türk halklarından biri de Gagauzlardır. Gagauzların bugün önemli bir bölümü Moldova’ya bağlı özerk bir bölge olan Gagauz Yeri’nde yaşamaktadır. Moldova'dan sonra bu Türk topluluğunun yoğun olarak bulunduğu yerler Ukrayna (Odessa ve Zaporojye), Bulgaristan ve Yunanistan olarak görülmektedir. Bu yerlerden başka Romanya, Rusya, Kazakistan, Kırgızistan, Özbekistan, Türkiye, ABD ve Brezilya gibi ülkelerde de Gagauz nüfusuyla karşlaşılmaktadır (Arnaut ve Hünerli, 2017: 17).

Besarabya (Moldova)'nın Bucak bölgesini yurt tutan Gagauzlar özerlik yolunda uzun yllar mücadele vermiştir. Onların bu yoldaki mücadelesi Moldova Parlamentosu'nun 23 Aralık 1994 tarihinde Gagauz Yeri Özerk Cumhuriyeti"ni tanıması sonucu zaferle sonuçlanmıştır.

Dinî bakımından Ortodoks Hristiyanlığa bağlı bir Türk topluluğu olan Gagauzların etnik kökeni ve adı üzerine farklı görüşler bulunmaktadır. Yerli ve yabancı araştırmacılar tarafından ileri sürülen bu görüşlerin çeşitliliğine bağlı olarak konuyla ilgili bir fikir birliğinin sağlanamamasından dolayı onlar ilmî kaynaklarda "gizemli kökleri olan halk" (Zayonçkovski 2018: 261) şeklinde tabir edilmektedir. Ancak Kowalski'nin (1949: 499) bir çalışmasında dil bilimsel incelemeler sonucu Gagauzların kimliğiyle ilgili ulaştığı veriler, onların farklı ve birden fazla Türk boyunun birleşiminden ortaya çıkmış bir topluluk olduğunu ortaya koymuştur (Özkan, 1996: 11).

Oğuz dil grubunda yer alan Gagauz Türkçesi, merkez (Komrat-Çadır Lunga) ve güney (Vulkaneşti) olmak üzere iki ağızdan meydana gelmektedir. Gagauz yazı dilinin temelinde merkez ağzının özellikleri bulunmaktadır. Pokrovskaya (2018: 168-170), Gagauz Türkçesindeki bu iki ağzın ortaya çıkışını Gagauzların Kuzeydoğu Bulgaristan'da bulundukları dönemde Bulgar Gagauzları ve Sahil, Grek (Gerçek) Gagauzları olarak iki gruba ayrılmalarına bağlar. Buna göre, merkez ağzını Bulgar Gagauzlarının, güney ağzını ise Sahil, Grek (Gerçek) Gagauzlarının meydana getirdiğini ifade eder.

20. yüzyılın ortalarına dek konuşma dili olarak kullanılan Gagauz Türkçesi ancak 1957 yılında yazı dili hâline gelebilmiştir. Gagauz Türklerinin yazılı edebiyatı da doğal olarak bu gelişme paralelinde oluşmaya başlamıştır. Gerek Gagauz Türkçesinin bir yazı dili hüviyeti kazanması gerekse Gagauz 
edebiyatının gelişimi yolunda ilk ve önemli adımlar Mihail Çakir tarafından atılmıştır. Bu amaçla pek çok dinî muhtevaya sahip eseri Gagauz Türkçesine tercüme etmiş ve Kişinev'de dinî bir gazete çıkarmış olan Çakir, aynı zamanda Dictionar Gagauzo (Tiurko)-Romîn adıyla Gagauzca bir sözlük yayımlamıştır. Mihail Çakir, bu süreçte Gagauzların kimliği ve tarihi üzerine de yayınlar yapmıştır (Argunşah ve Argunşah, 2007: 96-97; Özkan, 2017: 425). Ayrıca Mihail Çakir'in bu faaliyetlerinden önce Gagauz Türkçesiyle vücuda getirilmiş birkaç esere rastlanıldığını da belirtmek gerekir.

1957 yılına kadar Gagauz Türkçesiyle neşredilen bütün çalışmalar farklı alfabeler kullanılarak meydana getirilmiştir. Yani Moldova'nın, hâkimiyeti altında bulunduğu devlete göre bir süre kullanılan alfabeler değişiklik göstermiştir. Bu sebeple Çakir, ana diliyle hazırladığı eserlerini ilk etapta Rus-Kiril alfabesiyle, daha sonra Latin asıllı Rumen alfabesiyle yazmıştır.

Gagauz Türkleri kendilerine ait bir alfabeye 1957 yllında sahip olmuşlardır. Bu uğurda Gagauz aydınları büyük çaba harcamıştır. Daha başlangıçta Latin harflerinden oluşan bir alfabe talep edilmiş olsa da o dönemde başta bulunan Sovyet hükûmetinden dolayı Gagauzlar öncelikle Kiril esaslı bir alfabe kullanmıştır. Moldova'nın Sovyetler Birliği'nden ayrılmasından sonra Gagauzların Latin alfabesine geçme çalışmaları hız kazanmıştır. Nihayet 1993 yılında Moldova Parlamentosu'nun resmî kararı ile Latin alfabesine geçmişlerdir (Babaoğlu, 1999: 56-57-58).

Alfabe konusunda yaşanan ilk gelişmenin ardından farklı türlerde (şiir, hikâye, roman, tiyatro) verilen eserlerle giderek gelişmeye ve şekillenmeye başlayan çağdaş Gagauz edebiyatı şiir türüyle öne çıkmaktadır. Bu saha edebiyatının edebî türleri arasında örneklerine en fazla rastlanan ve en çok gelişme gösteren tür şiirdir. Nesir alanında ise hikâye türünün romana göre daha hızlı bir inkişaf süreci yaşadığı görülür. Gagauzların çağdaş edebiyatında roman türü, ortaya konan eser sayısı bakımından şiir ve hikâyenin gerisindedir. Bunda Gagauz Türkçesinin oldukça geç bir dönemde yazı dili olarak kullanılmaya başlanması, edebî dil düzeyine yükselebilmesi için belli bir zaman geçmesinin gerekliliği ile romanın uzun anlatıma ve ayrıntıya dayalı bir tür olmasının etkisi vardır. İlk iki etken elbette şiir ve hikâye alanında da kendisini göstermiştir. Misal, Gagauz edebiyatında henüz gelişme aşamasında olan edebî dille yazılan ilk şiirler sanat değeri açısından basit ve yetersiz bulunmuştur (Argunşah, 1996: 680).

Çă̆daş Gagauz edebiyatında roman başlangıçtan beri çok yavaş bir gelişim seyri takip etmiştir. Tespit edebildiğimiz kadarıyla bu sahada günümüze dek kaleme alınan toplam roman sayısı 6'dır. Bunlar yayımlandıkları yıl sırasına göre yazar bilgileriyle şöyledir: Uzun Kervan (1985) / Diyonis Tanasoğlu, Hacımançunun Çöşmesi (1994) / İvan Vlontir, Düşlär Havezlär (1997) / Evgeni Karagaur, Acı Pelin Bucakta (2011) (Özkan, 2017: 434), Zamannardan Avazlar (2016) / Vlad-Demir Karagançu, Kadem Kaynaa (2017) / Mariya Mercanka.

Gagauz Türklerince roman alanında ilk ürün 1985 yllında verilmiştir. Diyonis Tanasoğlu'nun Uzun Kervan adını verdiği bu romanda Gagauzların tarihi konu edinilmiştir. Hacımançunun Çöşmesi, tefrika romandır. Gagauzların en önemli yayın organı olan Ana Sözü gazetesinde bölümler hâlinde yayımlanmış fakat kitap hâlinde basımı yapılmamıştır (Özkan, 2017: 434). 1997 yllına ait üçüncü romandan sonra Gagauz edebiyatı roman konusunda on dört yllık bir boşluk evresine girmiştir. Yaşanan bu boşluk evresi nihayet 2011 yllında neşredilen Vlad-Demir Karagançu'nun Acı Pelin Bucakta romanıyla sona ermiştir. Karagançu, bundan beş yl sonra Gagauz edebiyatına bir roman daha kazandırmıştır. Onun bu eserini Mariya Mercanka’nın Kadem Kaynaa adlı romanı izlemiştir. 
$\mathrm{Bu}$ yazının oluşmasına kaynaklık eden Kadem Kaynaa romanı, çağdaş Gagauz edebiyatının roman dalında şu an için bilinen en yeni eseridir. Kadem Kaynaa, Gagauzların kadın yazar ve şairlerinden Mariya Mercanka'nın ilk romanıdır. Yazarın bundan önceki eserleri şiir ve hikâyelerden oluşmaktadır.

Mariya Mercanka, bu romanında 1970'li yllarda Bucak'ta Sovyet rejimi altında bulunan Gagauz köylülerin "kolektif tarım" şeklinde tanımlanan kolhoz sistemi içindeki hayatını ele almıştır. Romandaki tema bundan ibaret olmakla birlikte konu Almalık Köyü’nde harap hâlde bulunan ve Kristina tarafından inşası istenen anaokuludur. Kristina İvanovna, romandaki iki başkahramandan biridir. Öğretmen olan Kristina aynı zamanda anaokulunun yönetiminden sorumludur. Diğer başkahraman kolhoz yöneticisi olarak karşımıza çıkan Andrey Konstantinoviç Mercan'dır. Roman boyunca olaylar bahsedilen anaokulunun inşası ile bu iki başkahraman çevresinde şekillenir. Daha başka birçok kişi de romandaki olay örgüsüne dâhildir. Kadem Kaynaa şahıs kadrosu oldukça geniş bir romandir.

Romanın içeriğine hâkim olan ve eseri okurken kolaylıkla sezilen bir konu daha vardır. Bu da Andrey ve Kristina adındaki iki gencin birbirlerine karşı duydukları ilgi ve sevgidir. Öyle ki, inşa edilen anaokulu yazar tarafından Andery’in Kristina’ya beslediği gerçek sevgisinin bir işareti olarak yorumlanmıştır. Bununla gerçek ve büyük bir sevginin gücü vurgulanmak istenmiştir.

Eserdeki olayların geçtiği yıllar SSCB'nin iktisadi, siyasi ve sosyal açıdan durgunluk içerisinde bulunduğu bir dönemdir. Romanın ön sözünde bu dönem, vatan tuttukları Bucak topraklarının tarihteki en sıkıntısız ve en mutlu zamanları olarak belirtilmiştir (Mercanka, 2017: 3).

Yazar, roman içerisinde Sovyetler Birliği'nin durgunluk dönemine, kolhoz sisteminin işleyişine değinerek okuyucuyu o yıllara dair bilgilendirmektedir. Kısacası bu roman ile Gagauzların belirtilen yıllardaki gündelik ve sosyal yaşamı gözler önüne serilmektedir. Kadem Kaynaa romanında farkına varılan önemli bir nokta da Gagauz halkının geleneklerine olan bağlılı̆̆ıdır.

Romanda olaylar çoğunlukla Almalık denilen köyde geçmektedir. Fakat günümüzde ya da daha önceki bir zamanda Gagauz Yeri'nde bu adla bir köye rastlanmamaktadır. Yazar, aslında Almahk köyü ile doğup büyüdüğü Beşalma köyünü kastetmektedir.

Kitabın adıyla içeriği arasındaki ilişkiye değinecek olursak; romanın adında geçen kadem sözcüğü "mutluluk" anlamındadır. Romanda da Kadem Kaynaa adını taşıyan bir dere ilgi çekmektedir. Bu dere suyunun çevresine verdiği bereket ve mutluluktan ötürü bu şekilde adlandırıldığı düşünülmektedir. Ayrıca romanda birbirini seven iki gencin (Andrey ile Kristina) en mutlu anını Kadem Kaynaa adı verilen suyun kenarında geçirmesi sembolik bir olay olarak gözükmektedir. Bunlara göre yazar bu romanıyla bir yandan her insanın hayatta kendine bir mutluluk kaynağı aradığını ve bulduğunu ortaya koyarken bir yandan da o zamanlarda insanlar arasındaki ilişkilerden bahsederek ortak bir mutluluk kaynağı göstermektedir.

Romanlar yazınsal alanda olduğu kadar dil alanında da değerlendirmeye tabi tutulur. Özellikle söz varlığı çalışmalarında çokça kullanılan edebî türlerden biri romandır. Buna karşın çağdaş Gagauz ebediyatında şu ana kadar yayımlanmış romanların söz varlığı açısından incelendiği herhangi bir çalışmaya henüz denk gelinmemiştir. Hâlbuki Gagauz Türkçesinin, UNESCO'nun yayımladığı “Tehlikedeki Dünya Dilleri Atlası" içerisinde yer alması (http://www.unesco.org/languagesatlas/index.php), bu lehçenin söz varlığına yönelik çalışmaları daha önemli ve gerekli kılmıştır. Bu 
romanlar arasında ele aldığımız Kadem Kaynaa romanı, Gagauz Türkçesinin -yayımlandığı yıl itibarıyla- bugünkü söz varlığıyla ilgili değerli pek çok veriler sunmuştur.

Bu çalışmada Kadem Kaynaa romanının söz varlı̆̆ı ile romanda hâkim olan dil ve üslubun değerlendirmesi yapılmıştır.

\section{Romandaki söz varlı̆̆ının değerlendirilmesi}

Kadem Kaynaa romanının söz varlığına ilişkin genel tablo aşağıdaki gibidir:

\begin{tabular}{|l|l|}
\hline Unsurlar & Toplam Sayı \\
\hline İsim & 719 \\
\hline Fiil & 551 \\
\hline Deyim & 582 \\
\hline Atasözü & 6 \\
\hline İkileme & 83 \\
\hline Kalıp Söz & 23 \\
\hline
\end{tabular}

Tablo1. Kadem Kaynaa romanındaki söz varlığı unsurlarıyla ilgili sayısal veriler

Hazırlanan tez çalışmasında romandan derlenen 719 isim konularına göre4, 551 fiil ise yapılarına göre tasnif edilerek incelenmiş ve her iki sözcük türünün de eserde geçtiği yerler ile tekrar sayıları tablolar hâlinde gösterilmiştir. Burada, bu tablolardan yararlanılarak toplam adedi verilen isimler ve fiiller içerisinde romanda tekrar sayısı 10 ve üzeri olan sözcükler değerlendirilmiştir. İsim ve fiil sayısının oldukça yüksek olması çalışma içerisinde bu şekilde bir sınırlandırmayı zorunlu kılmıştır.

\section{1. İsimler}

Mariya Mercanka'nın Kadem Kaynaa romanından tekrar sayısı 10 ve bu sayının üstünde olan 81 farklı isim tespit edilmiştir. Aşağıdaki tabloda gösterilen bu isimler arasında yazarın romanında en sık küü (137), uşak (125), predsedatel (66), kolhoz (64), beygir (57), yortu (57), maşina (56), çorbacı (55), kolhoz başı (54), yasla (48), kur (36) ve kasaba5 (34) sözcüklerini kullandığı görülmüştür.

Romanda işlenen tema, olayların geçtiği dönem ve yerler (mekânlar) göz önünde tutulduğunda bu 10 sözcüğün yinelenme sıklığı bakımından en başta yer alması doğaldır. küü sözcüğünün isimler kategorisinde en sık geçen sözcük olması olayların romanda asıl ya da genel mekân şeklinde addedebileceğimiz Almalık köyü’nde geçmesinden ileri gelir. Bunun yanı sıra eserin olay örgüsü içerisinde Gagauz Yeri’ndeki başka köy ve kasabaların adları da zikredilir. Fakat yazar eserinde bu özel adları devamlı yinelemek yerine küü ve kasaba sözcüklerini daha sık kullanarak karşılamayı tercih etmiştir.

İkinci sırada gelen “çocuk” anlamındaki uşak sözcüğü, Gagauz Türkçesi ile Türkiye Türkçesi arasındaki ortak sözcüklerdendir.

424 başlık altında kategorize edilen isimlerle ilgili çalışmada yer alan başlıklar sırasıyla şöyledir: "bitkiler, hayvanlar, yiyecekler ve içecekler, giysiler ve aksesuarlar, organlar, tıp ve hastalık, akrabalık, araç gereç ve eşyalar, meslekler ve unvanlar, iklim, hava ve tabiat olayları, coğrafya, mekânlar, mevsim, ay ve günler, takvimler, yönler, taşıtlar ve makineler, hukuk, din, yönetim ve siyaset, eğitim, dans ve müzik, resim, sinema, felsefe, sosyoloji, mantık." (Erdin, 2020: 25-146).

5 Gagauz Türkçesinde kasaba sözcügü “şehir" anlamında kullanılmaktadır. 
Romanda 57'şer defa tekrar eden beygir ve yortu sözcükleri bu bölümde dikkat çekmek istediğimiz diğer sözcüklerdir. Aşağıdaki tabloya bakıldığında yazarın romanda Farsça kökenli beygir sözcüğüne karşılık bunun eş anlamlısı olan at sözcüğünü6 yalnızca 12 kez yinelemiş olması göze çarpar. Bu da bir bakıma Gagauz Türkçesinde beygir sözcüğünün daha fazla kullanıldığına işaret eder. Bilindiği gibi Gagauz kültürü, kutlanılan bayramlar ve bu bayramlara bağlı olarak gerçekleştirilen âdetler yönünden oldukça zengin ve renkli bir görünüme sahiptir. Mariya Mercanka da romanında Gagauz halkının pek çok yortusuna, âdetlerine ve halk inanışlarına yer vermiş ve bunları romandaki olaylarla başarılı bir şekilde harmanlamıştır. Gagauzların ilkyaz yortularından biri olan Ayoz Todur günü veya Ay Todur günü doğrudan atlarla ilgilidir (Çimpoeş 2018: 17, 21). Mariya Mercanka, romanda bu güne özel at yarışlarının düzenlendiğini anlatır. Ayrıca onun roman kahramanları arasında eserde adı sıkça geçen "Tarpan” isimli bir ata yer verdiği görülür. Özetle yazar tüm bunlarla Gagauz Türklerinde atın ne denli önemli ve özel bir yere sahip olduğunu göstermeye çalışmıştır. Aynı zamanda romanda at ile ilintili daha birçok adlandırmayl ${ }^{7}$ kullanarak Gagauz kültüründe atın önem derecesine dikkat çekmek istemiştir. Yine tabloya göre kuş sözcüğünün tekrar sayısının yüksek olmasında et orucunun etkisi vardır. Büyük oruçtan bir hafta önce tutulan bu oruçta cumartesi günü âdet olduğu üzere kesilen kuşlardan çeşitli et yemekleri yapılır. Yani yazar kuş sözcüğünü romanda yer yer "tavuk" anlamına gelecek şekilde kullanmıştır.

Tabloda bulunan eş veya yakın anlamlı sözcükler aslında yazarın dili kullanımına ve söz dağarcığının çeşitliliğine örnektir. Örneğin, yazar romanında "yönetici, başkan, baş, sahip" anlamında "çorbacı, kolhoz başı, önderci ve predsedatel” gibi farklı sözcükleri kullanmaya özen göstermiştir. Bunları bazen birbirinin yerine kullanarak anlatımın tekdüze bir hâl almasını önlerken diğer örneklerin görülmesini de mümkün kılmıştır. Bu hususa tablo içinden gösterebileceğimiz başka bir misal eş anlam alanına sahip olan yasla ve uşak başçası sözcükleridir. Bir yer belirtmeleri yanında eğitim-öğretim alanıyla ilgili olan bu sözcükler yinelenme sıklıkları bakımından mukayese edildiğinde "anaokulu, kreş" için Rusça yasla sözcüğü eserde daha fazla kullanılmıştır. Son olarak yazar romanında aile kavramını karşılamak amacıyla Arapça kökenli ayle ${ }^{8}$ yanında sensele sözcüğüne de başvurmuştur. Bu iki sözcüğün tekrar sayısı arasında önemli bir fark gözlenmez ancak sensele sözcüğü eserin çoğu yerinde "akraba, sülale" anlamında karşımıza çıkar.

Yazarın eserde sıkça kullandığı sözcükler arasında akrabalık alanına ait sözcükler dikkati çeker. Tabloda ana ve boba terimlerinden başka batü, gelin, güvää, kaku, kızkardaş, koca, komuşu, ool, svatä şeklinde dokuz ayrı akrabalık/yakınlık bağını ifade eden terimlerin yer alması tıpkı diğer Türk topluluklarında olduğu gibi Gagauz Türklerinde de aile ve akrabalık bağlarına verilen değeri ve bu değerin korunduğunu ortaya koyar. Zira, Türkçede aileyi oluşturan bireylerden her birini karşllayan farklı bir sözcüğün bulunması aradaki ilişkilerin daima canlı ve sıkı olmasına dolayısıyla bu ilişkilere gösterilen öneme bağlanır. Söz konusu durum tabii olarak dile yansımıştır. Üstteki on bir akrabalık teriminden yedi tanesinin kan yoluyla oluşan birinci ve ikinci derece akrabalıklardan meydana geldiği görülür. Romandan ulaşılan Gagauz Türkçesine ait akrabalık terimleri buradaki on bir sözcükle sınırlı değildir.

Mariya Mercanka'nın Kadem Kaynaa romanında sıklıkla geçen sözcüklerin sıralandığı aşağıdaki tabloya göz atıldığında çiftçi, çayır, kır, inek, süt, kuzu, şarap, manca, yahnı, bal, klise, oruç,

\footnotetext{
6 Önceleri Gagauzlar arasında yaygın olarak kullanılan “at” sözcüğ̈̈ zamanla yerini “beygir” sözcüğ̈̈ne bırakmıştır. Bunda Gagauzların yaşam biçiminde meydana gelen değişiklik etkili olmuştur (Hünerli, 2019: 110).

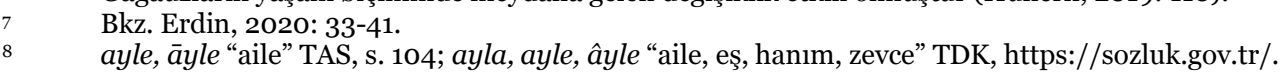

Adres

Kırklareli Üniversitesi, Fen Edebiyat Fakültesi, Türk Dili ve Edebiyatı Bölümü, Kayalı Kampüsü-Kırklareli/TÜRKİYE e-posta: editor@rumelide.com
Address

Kurklareli University, Faculty of Arts and Sciences, Department of Turkish Language and Literature, Kayalı Campus-Kırklareli/TURKEY e-mail: editor@rumelide.com 
allaa/allah vb. sözcükler Gagauz Türklerinin yeme içme kültürü, geçim kaynakları, dinî inancı kısaca onların hayat tarzıyla alakalı ipuçları vermektedir.

\begin{tabular}{|c|c|c|}
\hline İsim & Anlamı & Tekrar Sayısı \\
\hline allaa & allah & 11 \\
\hline allah (Ar.) & bkz. allaa & 15 \\
\hline ana & ana, anne & 39 \\
\hline at & at, beygir & 12 \\
\hline aul (Yun. aule) & avlu & 29 \\
\hline avtobus (Rus .авто́бус) & otobüs & 20 \\
\hline ayle (Ar. âile) & aile & 10 \\
\hline bal & bal & 15 \\
\hline batü (Bulg.) & ağabey & 23 \\
\hline beygir (Fa. bâr-gîr) & beygir & 57 \\
\hline boba & baba & 34 \\
\hline bolniţa (Rus. больнйца) & hastane & 20 \\
\hline brigadir (Rus. брига́дй) & grup şefi, ustabaşı, ekip başı & 26 \\
\hline Bucak & $\begin{array}{l}\text { Bucak, Moldova'nın güneyindeki } \\
\text { yere verilen bölgenin adıdır. }\end{array}$ & 10 \\
\hline çayır & çayır & 20 \\
\hline çiçek & çiçek & 23 \\
\hline çiftçi & çiftçi & 14 \\
\hline çorbacı & sahip & 55 \\
\hline dere & dere & 19 \\
\hline döşek & döşek, yatak & 14 \\
\hline fidan (Yun. fitáni) & fidan & 12 \\
\hline fidancık (Yun. fidan+T. clk) & fidancık & 10 \\
\hline filcan & fincan & 19 \\
\hline gelin & gelin & 22 \\
\hline güvää & güveyi, damat & 12 \\
\hline hava (Ar. hevâ) & hava & 21 \\
\hline ilkyaz & ilkbahar & 28 \\
\hline imek & yemek & 22 \\
\hline inek & inek & 12 \\
\hline institut (Rus. институ́т) & enstitü & 10 \\
\hline işçi (iş+çi) & işçi & 11 \\
\hline kaar & kar & 28 \\
\hline kabinet (Rus. кабинѐт) & oda & 26 \\
\hline kaku (Bulg. káka) & abla & 18 \\
\hline
\end{tabular}




\begin{tabular}{|c|c|c|}
\hline kasaba (Ar. kasaba) & şehir & 34 \\
\hline kır & kır & 36 \\
\hline kış & kış & 16 \\
\hline kızkardaş & kız kardeş & 12 \\
\hline Kişinöv & Kişinev & 21 \\
\hline klise (Yun. eklisia) & kilise & 14 \\
\hline koca & koca, eş & 10 \\
\hline kolhoz (Rus. колхо́з) & kolektif çiftlik & 64 \\
\hline kolhoz başı (Rus. колхо́з+T. baş+1) & çiftlik yöneticisi & 54 \\
\hline komuşu & komşu & 17 \\
\hline kontora (Rus. конто́ра) & büro, ofis & 21 \\
\hline köpek & köpek & 26 \\
\hline kuzu & kuzu & 16 \\
\hline kuş & kuş & 27 \\
\hline küü & köy & 137 \\
\hline lüzgär (Fa. rüzgâr) & rüzgâr & 12 \\
\hline manca (İt. mangia) & yemek & 10 \\
\hline maşina (Rus. машѝна) & otomobil, araba & 56 \\
\hline medsestra (Rus.медсестра́) & hemşire & 11 \\
\hline muzey (Rus. музѐй) & müze & 11 \\
\hline muzıka (Rus. музыка) & müzik & 15 \\
\hline ool & oğul & 26 \\
\hline oruç (Fa. rûze) & oruç & 11 \\
\hline oturuş (otur-uş) & toplantı & 15 \\
\hline önderci (önder+ci) & yönetici & 15 \\
\hline predsedatel (Rus. председа́тель) & başkan & 66 \\
\hline ruba (Rus. póбa) & giysi & 18 \\
\hline saalık & sağllk & 14 \\
\hline sensele (Ar. silsile) & aile, sülâle & 18 \\
\hline speţialist (Rus. специалйст) & uzman & 12 \\
\hline saurgun & bora, tipi, firtına & 12 \\
\hline süt & süt & 10 \\
\hline svatä (Rus. сват) & dünür kadın & 11 \\
\hline şarap (Ar. şerâb) & şarap & 18 \\
\hline şkola (Rus. шко́ла) & okul & 10 \\
\hline tokat & sokak, avlu, bahçe kapısı & 49 \\
\hline tafta (Fa. tahte) & tahta & 15 \\
\hline türkü & türkü & 14 \\
\hline usta (Fa. üstâd) & usta & 18 \\
\hline
\end{tabular}




\begin{tabular}{|l|l|l|}
\hline uşak & uşak & 125 \\
\hline uşak başçası & anaokulu & 13 \\
\hline yaamur & yağmur & 25 \\
\hline yahnı (Fa. yahnî) & yahni, et, et yemeği & 18 \\
\hline yasla (Rus. ясли) & anaokulu, kreş & 48 \\
\hline yaz & yaz & 11 \\
\hline yımırta & yumurta & 16 \\
\hline yortu (Yun. eorti) & bayram & 57 \\
\hline zal (Rus. зал) & salon & 25 \\
\hline
\end{tabular}

Tablo2. Tekrar sayısı 10 ve üzeri olan isimler

\subsection{Fiiller}

Bu başlık altındaki fiiller gramatik açıdan değerlendirilmiş ve roman yazarının basit, türemiş ve birleşik fiil kullanma oranına bakılmıştır.

Romandan ulaşılan 519 fiil içinde ölçüt olarak belirlediğimiz tekrar sayısına veya bu sayının yukarısına sahip 49 fiil bulunur. Bunlardan 46'sının birbirinden farklı fiiller olduğu görülür. Bu fiiller, Gagauz Türkçesinde bir kısım iş ve davranışın hangi eylemler vasıtasıyla ne şekilde karşılandığını göstermesi açısından önemlidir. Ayrıca tablodaki fiil türünden sözcükler Gagauz Türkçesinde fiil türetme yolları ile bu işlemde görev alan eklerin neler olduğunu gözleme ve belirleme firsatı sunmuştur.

Alttaki tabloda 48 fiille ilgili sunulan veriler oranlandığında anna- (108), çeket- (6o), alatla- (47), duy- (44), lafet- (40), duyul- (34), etiş- (3o), annaşıl- (28), peydalan- (27), siiret- (27), işit- (25) ve yollan- (25) yazarın romanda en çok kullandığı fiiller olarak belirlenmiştir. Gerek bu siralamada gerekse tabloda STT ile benzer olduğu görülen birçok fiil dışında Gagauz Türkçesinde kullanıldığı saptanan çeket-, alatla-, şıla-, sesirgen-9 ve yavaşı- fiillerine Türkiye Türkçesi ağılarında rastlanılmaktadır. Diğer taraftan "korkutmak, tehdit etmek" anlamındaki yaan- fiilinin ise bünyesinde barındırdığı asli “aa” ünlüsü ve anlamıyla Gagauz Türkçesine has bir fiil olduğu anlaşılmaktadır.

Yapılan sıralamada yer alan duy- ve bunun - $l$ fiilden fiil yapım ekiyle genişletilmiş şekli olan duyulfiilleri romanda "hissetmek, sezmek" manasında karşımıza çıkmıştır. Gagauz Türklerince fiilin sadece belirtilen anlamlarıyla kullanıldı̆̆ Gagauz Türkçesi Sözlüğü’nden ${ }^{10}$ teyit edilmiştir. Taranılan eserde duy- fiilinin Türkiye Türkçesindeki gibi "bir şeyi haber almak; ses almak" (TDK, 1998: 649) şeklinde kullanımına denk gelinmemiş, bunların işit- fiiliyle ifade edildiği görülmüştür.

Tabloda yapıca farklılık gösteren fiiller yer almaktadır. büü-, uu-, ur- şeklindeki basit fiillerin yanı sıra çeşitli ekler ve yardımcı fiiller yoluyla oluşturulmuş türemiş ve birleşik fiiller bulunmaktadır. Yazarın romanını oluştururken türemiş ve birleşik yapıda olan fiilleri daha fazla kullandığı görülmektedir. 321 türemiş fiil, 116 birleşik fiil kullanmıştır.

\footnotetext{
$9 \quad$ Sesirgen- fiili Türkiye Türkçesi ağızlarında Gagauz Türkçesindeki anlamından farklı anlamlarda kullanılmaktadır (DS: 3592; TAS: 888).

Ayrıca +irgen- ekiyle ilgili detaylı bilgiler için bkz. (Özkan, 1996: 109). 
Türemiş fiiller bahsinde; isimden fiil yapan +la-/+na- (işle-, baaşla-, sesle-), +a- (oyna-, yavaşı-), +irgen- (sesirgen-); fiilden fiil yapan -(ı)l- (iil-, atıl-, işidil-), -gun- (durgun-), -gut- (durgut-), -ş(etiş-, daalış-), -n- (sölen-), -t-, (yavaşıt-), -dir- (üreklendir-) ekleri kullanılarak türetilmiş fiil örnekleriyle karşılaşılmıştır. Bu eklerden - gut $^{-11}$ ve $-g u n^{-12}$ hariç diğerlerinin Türkiye Türkçesinde de fiil türetmede yaygın bir şekilde kullanılan ekler olduğu görülmüsştür. Romanda, -gut- ve -guneklerinin yer aldığı birer örnek saptanmıştır. Nevzat Özkan'ın Gagavuz Türkçesi Gramerìnde de bu iki ekin romanda karşılaşıldığı gibi sadece dur- fiilinde yaşadığı tespit edilmiştir (Özkan 1996: 116).

Tablodaki örneklere göre Gagauz Türkçesinde birleşik fiiller oluşturulurken et- ve ol- yardımcı fillerinden istifade edilmiştir. İsim veya fiil üzerine eklenen bu yardımcı fiillerle Türkçenin dil mantığına uygun bir şekilde yeni fiiller türetme yoluna gidilmiştir. af et-, prost et-, lafet-, seset-, mayıl ol- vb. örneklerde isim unsuru sözcükler bu yardımcı fiiller yoluyla fiilleştirilerek yüklem durumuna getirilmiştir.

Ayrıca et- ve ol- yardımcı fiillerinin kök hâlindeki bir fiil üzerine getirildiği örneklerle de karşılaşılmıştır. Tabloda bahsedilen hususa örnek teşkil eden çeket- fiili yer alır. Ek olarak romandan baset- (kendini bir şey üzerine brrakmak, sarkmak, atmak; firlatmak) ve sus ol- (sessizlik olmak) fiillerine ulaşılmıştır.

Öte yandan $e t$ - ve ol- yardımcı fiilleriyle birlikte Türkçenin işlek bir isimden fiil yapım eki olan +la'nın, Gagauz Türkçesine türlü yollardan girmiş yabancı kökenli sözcüklerle kullanımı göze çarpmıştır. Bu sayede; Ar. duva + T. et-, Fa. laf + T. et-, Bulg. prost + T. et-; Ar. zeet (eziyet) + T. le-, resim Ar. + T. ne- örneklerinde görüldüğü gibi Arapça, Farsça ve Bulgarcadan alıntı sözcüklerin Türkçeleşmesi sağlanmıştır.

\begin{tabular}{|l|l|l|}
\hline Fiil & Anlamı & Tekrar Sayısı \\
\hline aala- & ağlamak & 11 \\
\hline af et- (Ar. afv + T. et-) & affetmek & 11 \\
\hline alatla- & acele etmek & 47 \\
\hline anna- & anlamak & 108 \\
\hline annaşı- & anlaşılmak & 28 \\
\hline atıl- & $\begin{array}{l}\text { 1. reddetmek. } \\
\text { 2. uzaklaştırılmak. } \\
\text { 3. vazgeçmek. }\end{array}$ & 15 \\
\hline baaşla- & bağışlamak, hediye etmek & \\
\hline büü- & büyümek & 10 \\
\hline çeket- & başlamak & 15 \\
\hline daalış- & dağllmak, ayrılıp uzaklaşmak & 60 \\
\hline daat- & dağıtmak & 15 \\
\hline dala- & isırmak & 10 \\
\hline diişil- & değişme işine konu olmak, değişmek, biçim veya & 10 \\
\hline
\end{tabular}

\footnotetext{
11 -gut-, Eski Türkçe ve Orta Türkçe devrinde örneklerine rastlanan bir ektir. Ek, Eski Türkçe devrinde -gut-/-güt-, kut/küt-, kut-/kit-; Karahanlı sahasında kut-/kit-/kut-/küt- ve Harezm sahasında -gut-/-güt- şeklindedir (Hacıeminoğlu, 2016: 41, 61, 95).

12 Tarihî ve yaşayan diyalektlerde -gun- ekinin varlığına dair bir kullanıma rastlanmamıştır (Özkan, 1999: 116).
} 


\begin{tabular}{|c|c|c|}
\hline & durum değiştirmek. & \\
\hline dinnen- & dinlenmek & 18 \\
\hline durgun- & $\begin{array}{l}\text { 1. durmak. } \\
\text { 2. üstüne düşmek, vakit harcamak, ilgilenmek. } \\
\text { 3. bir yerde durmak, oraya yerleşmek. } \\
\text { 4. durmamak, kalmamak. } \\
\text { 5. durmadan, sürekli tekrarlanmak. }\end{array}$ & 14 \\
\hline durgut- & $\begin{array}{l}\text { 1. durdurmak. } \\
\text { 2. (soluğunu) tutmak }\end{array}$ & 12 \\
\hline $\begin{array}{l}\text { duva et- (Ar. duâ' + T. } \\
\text { et-) }\end{array}$ & dua etmek & 12 \\
\hline duy- & hissetmek & 44 \\
\hline duyul- & $\begin{array}{l}\text { 1. hissedilmek. } \\
\text { 2. (bir söz, haber ya da koku) her yere yayılmak. }\end{array}$ & 34 \\
\hline etiş- & $\begin{array}{l}\text { 1. yetişmek, varmak, gelmek. } \\
\text { 2. büyümek, yetişmek. }\end{array}$ & 30 \\
\hline iil- & eğilmek & 11 \\
\hline işit- & duymak & 25 \\
\hline işidil- & işitilmek, duyulmak & 21 \\
\hline işle- & $\begin{array}{l}\text { 1. çalışmak, iş yapmak. } \\
\text { 2. (toğrağı) işlemek. } \\
\text { 3. bir şey veya bir yer iyi çalışmak }\end{array}$ & 18 \\
\hline itir- & ittirmek & 23 \\
\hline kapil- & $\begin{array}{l}\text { 1. bir şeye veya bir kimseye kapılmak, etkisinde } \\
\text { kalmak. } \\
\text { 2. ansızın yakalamak, çekip kapmak. } \\
\text { 3. sürüklenmek. }\end{array}$ & 11 \\
\hline $\begin{array}{l}\text { kaybet- (Ar. gayb + T. } \\
\text { et-) }\end{array}$ & $\begin{array}{l}\text { 1. bir kişinin dostluğunu, arkadaşlığını kaybetmek. } \\
\text { 2. bir şeyi veya bir kimseyi yitirmek. } \\
\text { 3. bir şeyin değeri düşmek. }\end{array}$ & 15 \\
\hline lafet- (Fa. lâf + T. et-) & konuşmak, sohbet etmek & 40 \\
\hline $\begin{array}{l}\text { mayll ol- (Ar. mâil + T. } \\
\text { ol-) }\end{array}$ & kayran olmak, beğenmek & 14 \\
\hline oyna- & $\begin{array}{l}\text { 1. eğlenmek, oyalanmak gibi maksatlarla bir şeyle } \\
\text { meşgul olmak, uğraşmak. } \\
\text { 2. kımıldamak. } \\
\text { 3. müzik eşliğinde hareket etmek. }\end{array}$ & 18 \\
\hline $\begin{array}{l}\text { peydalan- (Fa. peydâ + } \\
\text { T. la-n-) }\end{array}$ & peydahlanmak, oluşmak, ortaya çıkmak. & 27 \\
\hline $\begin{array}{l}\text { prost et- (Bulg. prost + } \\
\text { T. et-) }\end{array}$ & affetmek & 10 \\
\hline $\begin{array}{l}\text { resimne- (Ar. resm + T. } \\
\text { ne-) }\end{array}$ & resim yapmak, resmetmek & 12 \\
\hline sarmaş- & sarılmak, yanaşmak & 11 \\
\hline sesirgen- & bir şeye kulak vermek, o şeyi dinlemek ve duymak. & 20 \\
\hline
\end{tabular}




\begin{tabular}{|c|c|c|}
\hline seset- & seslenmek & 14 \\
\hline sesle- & dinlemek, söz dinlemek. & 12 \\
\hline siiret- & Seyretmek & 27 \\
\hline sölen- & $\begin{array}{l}\text { 1. söyleme işi. } \\
\text { 2. söylenmek, kendi kendine konuşmak. }\end{array}$ & 12 \\
\hline Şla- & Parlamak & 13 \\
\hline ur- & $\begin{array}{l}\text { 1. elindeki bir şeyi ya da elini bir yere hızlı bir biçimde } \\
\text { çarpmak. } \\
\text { 2. yansımak. } \\
\text { 3. hızla bir yere çarpmak. } \\
\text { 4. bir şeyi başka bir şey üzerine hızla çarparak ses } \\
\text { çıarmak. } \\
\text { 5. saplamak, kakmak. } \\
\text { 6. algılamak, hissedilmek. }\end{array}$ & 19 \\
\hline uu- & ovmak & 10 \\
\hline üreklendir- & cesaretlendirmek & 13 \\
\hline yaan- & korkutmak, tehdit etmek & 10 \\
\hline yakış- & yaraşmak, uymak, uygun olmak & 19 \\
\hline yavaş1- & $\begin{array}{l}\text { 1. yavaşlamak, bir şeyin sesi veya hızı alçalmak ya da } \\
\text { azalmak; hafiflemek. } \\
\text { 2. sakinleşmek. } \\
\text { 3. iş yapma ve hareket etme hızının azalması. }\end{array}$ & 15 \\
\hline yavaşıt- & $\begin{array}{l}\text { 1. sakinleştirmek, yavaşlatmak. } \\
\text { 2. yavaşlatmak, hızını kesmek. } \\
\text { 3. hafifletmek. }\end{array}$ & 10 \\
\hline yollan- & $\begin{array}{l}\text { 1. bir yerden çıkmaya kalkışmak. } \\
\text { 2. bir tarafa doğru yola koyulmak, yürümek. } \\
\text { 3. yeşillenmek. }\end{array}$ & 25 \\
\hline $\begin{array}{l}\text { zeetle- (Ar. eziyyet }+\mathrm{T} \text {. } \\
\text { le-) }\end{array}$ & eziyet vermek, üzmek & 15 \\
\hline
\end{tabular}

Tablo3. Tekrar sayısı 10 ve üzeri olan fiiller

\subsection{Alıntı sözcükler}

Romanda karşılaşılan farklı dillerden alınmış sözcükler analiz edildiğinde; Rusça başta olmak üzere Arapça ve Farsçadan alıntılanan sözcükler çoğunluğu oluşturmaktadır. Bu dillerin yanı sıra Rumen, Bulgar ve Yunan dilinden alıntılarla da karşılaşılmaktadır.

Bugün, Gagauz Türkçesi büyük ölçüde Rusça’nın etkisi altındadır. Ele alınan romanda Rusça alıntılara diğer yabancı dillere nazaran daha fazla rastlanılması bu etkinin açık bir delili sayılabilir. Ancak burada durum yazar açısından da yorumlanmalıdır. Mariya Mercanka'nın ana dili yanında Rusçayı da bilmesi ve hatta bir dönem Beşalma köyündeki bir okulda Rusça ders vermiş olması eserinde bu dilden alıntıları daha fazla kullanmasına yol açmış olabilir.

Alıntılar arasında tematik açıdan bir genelleme yapılacak olunursa; Rusçayla beraber Arapça ve Farsçadan alıntı sözcükler çoğu alana hâkim gözükmektedir. Rumence alıntıların daha çok bitkiler, 
yiyecekler, ev ve giyim eşyaları alanında olduğu görülmektedir. Yunanca alıntılar genellikle din, bitkiler ve araç gereçlerle ilgili sözcüklerden oluşmaktadır. Bulgarca sözcüklerin ise akrabalık alanında yoğunlaştığı göze çarpmaktadır.

Burada Gagauz Türkçesinin söz varlığında bulunan Arapça ve Farsça kökenli sözcüklerle ilgili konuya bir parantez açmak gerekir. Çünkü bu sözcükler Arapça ve Farsçadan doğrudan alınmamış, bunların Gagauz Türkçesine girişi farklı yollar aracılığıyla gerçekleşmiştir. Konuyla alakalı V. A. Siçeva başta olmak üzere Nevzat Özkan ve Bülent Hünerli13 tarafından yapılan araştırmalarda varılan ortak nokta Arapça, Farsça kökenli alıntı sözcüklerin Gagauz Türklerinin diline Türkiye Türkçesi ve ağızları yoluyla özellikle de Balkan Türk ağızları vasıtasıyla geçtiğinin belirtilmesi olmuştur. Her üç araştırmacı da Gagauz Türkçesindeki Arapça ve Farsça sözcüklerin büyük bir kısmının Türkiye Türkçesi ağızlarıyla gösterdiği fonetik uyumdan yola çıkarak bu sonuca ulaşmıştır (Hünerli, 2019: 1, 13-14; Özkan, 2018: 188). Çalışmanın bundan sonraki başlığında görüleceği gibi romandan tespit edilen bilhassa Arapça ve Farsça kökenli sözcüklerin Gagauz Türkçesine ağızlar üzerinden geçtiğini gösteren pek çok örneğin varlığına tanıklık edilmiştir.

Gagauz Türkçesindeki Arapça ve Farsça kökenli sözcüklerin bir bölümü dinî terimlerden oluşur. L. A. Pokrovskaya, Hristiyan inancına mensup Gagauzların dilinde görülen bu İslami tabirlerin, 19. yüzyllın sonunda Gagauzlar arasında yaygın olduğu bilinen Karamanlıca dinî kitaplar yoluyla Gagauz Türkçesine girdiğini belirtir. Devamında bu İslami terimlerin anlam olarak Hristiyanlık inancına göre yeniden kavramsallaştırıldığını ifade eder. Ayrıca Pokrovskaya, Gagauz dinî terminolojisinin oluşumunda Grek harfleriyle Türkçe olarak yazılmış Karamanlıca eserlerin açık bir şekilde etkisinin bulunduğundan da bahseder (Pokrovskaya, 2017: 422-425).

Kadem Kaynaa romanında tesadüf edilen İtalyanca, Fransızca ve İngilizce kökenli sözcükler ise Gagauz Türkçesine Rusça kanalıyla taşınmıştır. Örneğin; klarnet (Rus. кларнѐт < Fr. clarinette), kaktüs (Rus. ка́ктус < Fr. cactus), tango (Rus. та́нго < Fr. tango), veterinar (Rus. ветерина́p < Fr. vètèrinaire), seminar (Rus. семина́p < Fr. sèminaire), satin "saten, pamuklu atlas kumaş" (Rus. сатѝн < Fr. satin), narkoz (Rus. наркóз < Fr. narcose), vaza "vazo" (Rus. вáза < İt. vaso), student "öğrenci" (Rus. студѐит < İng. student) vb. Fakat Fransızca veya İtalyanca kökenli her sözcük için aynı şeyi söylemek doğru değildir. Romanda karşılaşılan Batı kökenli sözcüklerin bazısına Rusça Sözlük’te denk gelinmemiş olması bunların da tıpkı Arapça, Farsça kökenli sözcükler gibi Türkiye Türkçesinden ya da ağızlarından Gagauz Türkçesine girdiğini göstermektedir. Örneğin; GT manca < TAS manca < TT Manca < İt. mangia, GT tablo < TT Tablo < Fr. tableau gibi.

Ulaşılan örnekler bağlamında bu başlıkla ilgili aktaracağımız son husus Gagauz Türkçesinde pek çok Rusça alıntının değiştirilmeden Rusçadaki hâliyle kullanıldığıdır: kino "sinema" (кино), konţert "konser" (концѐрт), partorg "parti başkanı” (парто́рг), kanikul "okul tatili” (канѝкул), basurman "başka bir dinden, mezhepten olan" (басурма̀н) vb. Bu Slav dilindeki şeklinden farklı olarak kullanılan sözcük sayısı azdır. uçitilka "bayan öğretmen", (учѝтеьница, uchitel’nitsa), yasla "kreş, anaokulu" (ясли), semiçka “аус̧іс̧еğі” (сѐмечко), kasınka (косынка).

13 Hünerli, Mihail Çakir’in Gagauzca (Türkçe)-Rumence Sözlüğü’nde yer alan sözcükleri ses olayları bakımdan inceleyerek bu sözcükleri Türkiye Türkçesi ve Balkan Türk ağızlarıyla da karşılaştırmıştır (bkz. Bülent, Hünerli. (2019). Mihail Çakir’in Gagauzca (Türkçe)-Rumence Sözlüğ̈̈ (İnceleme- Metin), İstanbul: Paradigma Akademi).

Adres

Kırklareli Üniversitesi, Fen Edebiyat Fakültesi, Türk Dili ve Edebiyatı Bölümü, Kayalı Kampüsü-Kırklareli/TÜRKİYE e-posta: editor@rumelide.com 
Rusçaya göre Bulgarca ve Rumenceden yapılan alıntılarda genellikle bazı ufak ses değişiklikleri gözlemlenir: bomboni (Rum. bomboană), toloka "sürülmemiş tarla" (Rum. toloaká), kruça "haç" (Rum. cruce); batü (Bulg. báte), tätü (Bulg. тáте) vb.

\section{Rusça ve Rumence alıntılar}

agronom (Rus.) "tarım uzmanı, ziraat mühendisi”, ardey (Rum.) "biber”, blüdo (Rus.) "yemek", bomboni (Rum.) "bonbon şekeri”, borç (Rus.) "borş çorbası, bir çeşit Rus çorbası", feldşer (Rus.) "sağllk memuru", furkuliţa (Rum.) "çatal”, kasınka (Rus.) "üçgen şeklinde başörtü", kofta (Rus.) "bayan ceketi”, koftiçka (Rus.) "bluz”, kladovka (Rus.) "depo, mahzen”, komitet (Rus.) "komite”, kotlon (Rum.) "küçük soba tarzı ocak, firın", lavra (Rus.) "defne ağacı", lişa (Rus.) "egzama, deri hastalı̆̆ı", mamu (Rus.) "anne”, mangust (Rus.) "firavun faresi, gelincik sıçanı”, marar (Rum.) "dereotu”, paraliya (Rum.) "şapka”, peçenie (Rus.) "bisküvi”, pravlenie (Rus.) "idare, yönetim”, pirojnoe (Rus.) "kek, pasta”, portu (Rum.) "giyim, klyafet”, raţiya (Rus.) "telsiz telefon”, sarafan (Rus.) "kolsuz ve uzun kadın elbisesi”, semiçka (Rus.) "ayçiçeği”, sovhoz (Rus.) "devlet çiftliği”, stakan (Rus.) "bardak”, şarf (Rus.) "atkı”, şkola/skola (Rus.) "okul”, uçitilka (Rus.) "bayan öğretmen”, vertolöt (Rus.) "helikopter”, zakon (Rus.) "kanun, yasa”, zasedanie/zasedaniya (Rus.) "toplantı", zoopark (Rus.) "hayvanat bahçesi” vb.

\section{Yunanca ve Bulgarca alıntılar}

anatar (Yun.) "anahtar”, ayazma (Yun.) "okunmuş, kutsanmış su”, çotra (Yun.) "ağaçtan elde edilen su kabı”, koliva (Yun.) "haşlanmış buğday”, kirez (Yun.) "kiraz”, laana (Yun.) "lahana”, lelü (Bulg.) "hala, teyze”, panayır (Yun.) "daha çok küçük yerleşim yerlerinde kurulan büyük pazar.”, pelin (Yun.) "pelin otu, hekimlikte sağaltım amaçlı kullanılan bir bitki”, popaz (Yun.) "papaz”, röke (Yun.) "çırıı, el çlkrığı, öreke.", tätü (Bulg.) "baba (konuşma dilinde)” vb.

\section{Arapça ve Farsça alıntılar}

ahır (Fa.) "büyükbaş hayvanların bakıldığı ve barındığı örtülü yer", afta (Fa.) "hafta", cendem (Ar.) "cehennem”, çember (Fa.) "yazma, başörtüsü”, daul (Ar.) "davul”, divan (Ar.) "divan, sedir”, ecel (Ar.) "ecel, ölüm vakti”, fita (Fa.) "önlük”, genger (Fa.) "kenger, kengel, eşek dikeni”, horoz (Fa.) "horoz”, kalle (Fa.) "pirinç, lahana ve et karışımından elde edilen bir yemek", karanfil (Ar.) "karanfil, süs bitkisi”, kehle (Ar.) "bit”, lobut (Ar.) "bir sopa çeşidi”, pındık (Ar.) "yer findığı”, peşkir (Fa.) "havlu”, rakı (Ar.) "rakı", tabiat/tabiyat (Ar.) "doğa”, turşu (Fa.) "turşu”, zaabit (Ar.) "amir, subay”, tükän (Ar.) “dükkân”, zülüf (Fa.) "saç lülesi” vb.

\subsection{Trakya ve Anadolu (Türkiye Türkçesi) ağızlarıyla ortak olan sözcükler}

Araştırmamıza kaynaklık eden romanın söz varlığında Türkiye Türkçesi ağızlarında kullanılan sözcüklere rastlanılır. Standart Türkiye Türkçesinde bulunmayan bu sözcüklerin ağızlarda yaygın bir kullanımı olmakla beraber bir kısmı Gagauz yazı dilinde de görülür. Romandan Türkiye Türkçesi ağızlarıyla ortak olduğunu gördüğümüz sözcükler şunlardır: alatla- "acele etmek", aldangaç "oyuncak", almalık "elma bahçesi”, aylan- "bir şeyin etrafında dönmek, dolanmak", batlak "ağaçtan yapılmış küçük fiçı", çalmar "sundurma", çantı "kalça", çüven "kazan, tencere", direş- "gayret göstermek, direnmek, ayak diremek", dolayla- "bir yerin etrafında dolaşmak", donak "süs eşyalarının 
genel adı", elin "yelin", ense-14 "yenmek, bastırmak", esir-15 "şımarmak, azmak, delirmek; ötmek", fişkan "ince dal, fışkın”, geçin- "ölmek", ıh- "(bitki için) büyümek, gelişerek canlanmak", imik "beyin”, kalak "burun, hayvan burnu", kop et- "koşmak, hızla gitmek", kopuş- "başlamak", kuli "tay", kürtün "kar; kar yı̆̆ını", makak "koltuk değneği”, otalan- "zehirlenmek", pala (Fa.) "kilim, yaygı", pat "karyola, sedir", sallangaç "salıncak", sen- "durulmak, sakinleşmek", sergen "raf", sınaş- "alışmak", sındır-16 "bıktırmak; korkutmak, sindirmek", tokat "sokak, avlu veya bahçe kapısı", yalabı"parlamak".

Buraya kadar verilen sözcüklere hem Anadolu hem de Trakya ağızlarında rastlamak mümkündür. Ancak bunlardan başka sadece belli bir bölge ağzında kullanıldığı görülen örnekler de mevcuttur. Dolayısıyla bu örnekler Trakya Ağıları Sözlüğü ve Derleme Sözlüğü’nün yalnızca birinde bulunmaktadır. Misal, bir yön belirten gün duusu "doğu, gün doğusu" sözcüğüne Gagauz Türkçesindeki şekli ve anlamıyla Trakya Ağızları Sözlüğü’nde rastlanırken Derleme Sözlüğü’nde böyle bir kullanıma denk gelinmemektedir. Ayrıca misal gösterilen bu sözcüğün TAS’ye göre Doğu Rodop ve Kuzeydoğu Bulgaristan Türk ağızlarında kullanılması dikkat arz eden bir noktadır. karandaş (Rus.) "kurşun kalem" / DS, baset- "kendini bir şey üzerine atmak, bırakmak, firlatmak" / TAS, durgut"durdurmak; tutmak" / TAS, kombayna (Rus.) "biçerdöver" / TAS, kufne, kuhne (Rus.) "mutfak" / TAS, palatka "büyük çadır" / TAS vb. Genellikle ağızlara özgü olup Gagauz Türkçesinde kullanıldığını belirlediğimiz bu başlık altındaki sözcükler görüldüğü üzere birkaç istisna örnek dışında genellikle şekilce ve anlamca örtüşmektedir. Bu sözcüklerin bazısının yabancı kökenli olduğu görülmektedir.

Diğer taraftan Gagauz Türkçesi söz varlı̆̆ında STT ile ortak pek çok sözcük de yer alır. Fakat bunların önemli bir kısmında fonetik ve morfolojik farklılaşmalar gözlenir. Bu noktada Gagauz Türkçesinin, genelde Türkiye Türkçesi ağızları özelde Balkan Türk ağızlarıyla büyük benzerliklere sahip bir lehçe olduğu aşağıdaki örnekler üzerinde yapılan karşılaştırmalar neticesinde görülmektedir. Romandan derlenen sözcüklerin bir bölümü ile bunların TAS ve DS'de bulunanları arasında fonetik bakımdan bir uyum vardır.

aaç "ağaç" TAS, aaz "ağız" TAS; afta "hafta" TAS; auç "avuç" TAS; baala- "bağlamak" TAS; baaşla"bağışlamak, hediye etmek" TAS, DS; betva "beddua" DS17; boba "baba" TAS, DS; bua/buva18 "boğa" TAS, DS; buaz "boğaz" TAS, DS; çiidem "çiğdem, bir çiçek türü" TAS; daa "orman" TAS; dartı "başörtüsü” DS; daul "davul” TAS; dii- "değmek, dokunmak" TAS; duu- "doğmak” TAS; dübek "dibek, havan” TAS, DS; et- "yetmek” TAS; giisi "giysi” TAS; güüde "gövde” TAS; güüs "göğüs” TAS; hodullan"büyüklenmek, kabadıyalanmak" DS; izmetçi "hizmetçi” TAS; kirez "kiraz" TAS, DS; koola"kovalamak" TAS; küü "köy" TAS; laana "lahana" TAS; lalangı "tatlı bir çörek çeşidi” TAS, DS; maale "mahalle" TAS, DS; ool "oğul” TAS, DS; raametli "rahmetli" TAS; saalık "sağlık" TAS; sur "sığır" TAS, DS; suvan "soğan" TAS, DS; suazla-/suvazla- "sivazlamak" TAS; süüt "söğüt” TAS; tauk "tavuk" TAS; tüü "tüy” TAS; ur- "vurmak” TAS, DS; uu- "ovmak” TAS; ürek "yürek” TAS, DS; üz “yüz, çehre” TAS, DS; yaamur "yağmur TAS; yımırta "yumurta” TAS, DS; yardımnamak "yardım etmek" TAS; yuurt "yoğurt” TAS; zerdeli "zerdali” TAS, DS vb. Sözcüklerin oluşturduğu bu tablodan da anlaşıldığı gibi Gagauz Türkçesi sahip olduğu dil özellikleri bakımından Türkiye Türkçesi ağızlarıyla ortaklıklar taşımaktadır. Verilen örnekler içerisinde iç veya son sesteki “ $\breve{g}, y, v, h$ ” ünsüzlerinin erimesi sonucu meydana gelen uzun ünlülü (aa, ee, ii vb.) sözcüklerin yoğunluğu göze çarpmaktadır. Yukarıdaki

TAS ve DS'de yense-, yensi- şeklindedir (TAS: 1098, DS: 4248).

Fiilin "ötmek" anlamı Gagauz Türkçesine mahsustur.

TAS'de sındī- şekliyle yer alan bu fiilin Deliorman Türk ağızlarında kullanıldığı görülmektedir (TAS: 893).

Sözcük DS'de bedva şeklindedir (DS: 597)

Anadolu ağızlarında buva şekli farklı anlamlarda kullanılmaktadır.

Adres

Kırklareli Üniversitesi, Fen Edebiyat Fakültesi, Türk Dili ve Edebiyatı Bölümü, Kayalı Kampüsü-Kırklareli/TÜRKİYE e-posta: editor@rumelide.com 
örnekler dâhilinde, bahsedilen şekilde olan sözcüklerin tümüne TAS'de rastlanıldığı buna karşllık DS'de bulunanların ise oldukça az sayıda olduğu görülmektedir. Bunun haricinde Gagauz Türkçesinde farklı sebeplere bağlı olarak ortaya çıkan daha başka pek çok ses olayı bakımından hem Anadolu hem de Trakya ağızları ile müşterek kullanımlara denk gelinmektedir.

Kadem Kaynaa romanında yer alan isimlerden arpa, ayak, bacak, bozkır, ceviz, çimen, çorbac1 ${ }^{19}$, dil, diş, düzen²o, ekin, eldiven, gemi, göl, göz, hergele, horoz, işçi, karaca, kaşık, keçi, kavalcı, kilim, kısrak, kulak, kurak, müdür, otlak, ördek, saç, sarmaşık, turşu, üzüm, yanak, yarık, yorgan; fiillerden ayaklan-, dal-, gagala-, kaçın-21, kon-, köstekle-, lafet-, oyna-, ört-, pişir-, sap-, sarar-, savaş-22, serpil-, silkin-, şükür et-, tertiple-, yokla- gibi sayısı daha da arttırılabilecek olan bu sözcükler sesçe veya yapıca herhangi bir değişime uğramayarak STT'deki hâliyle Gagauz Türkçesinde kullanılan örneklerdir. Karşılaştırma yapılırken sözcüklerin ses ve yapılarına olduğu kadar anlamlarına da dikkat etmek gerekir. Zira bir sözcük dil hususiyetleri bakımından uyum gösterse de anlam bakımından farklılaşabilir. Örneğin, Gagauz Türkçesinde çorbacı, düzen, savaş-, kaçınsözcükleri STT'den anlamca ayrılmaktadır.

\subsection{Deyimler, atasözleri, ikilemeler ve kalıp sözler}

Deyim, atasözü, kalıp söz ve ikileme gibi kalıplaşmış söz öbeklerine edebî türlerin birçoğu içerisinde rastlanılmaktadır. Bu söz öbekleri birbirinden farklı özelliklere sahip olsalar da kullanıldıkları bağlam veya iletişim biçimi fark etmeksizin her koşulda ifadenin daha çarpıcı bir hâle gelmesini sağlamaktadır. Sözcüklerin yinelenmesi esasına dayanan ikilemeler anlamın pekiştirilmesinde; deyim, atasözü ve kalıp sözler bir duruma özgü duygu ve düşüncelerin iletilmesinde kullanılmaktadır. Dolayısıyla her şair ve yazar bir yapıt vücuda getirirken konuştuğu dilin bu imkân ve zenginliklerine başvurarak daha güçlü ve renkli bir anlatım yakalamıştır.

Mariya Mercanka da romanını deyim, atasözü, ikileme ve kalıp sözlerle işleyerek anlatımını daha etkili ve çekici kılmıştır. Romanını oluştururken bu söz öbeklerinden en çok deyimler ile ikilemelere başvuran yazarın deyimlere hepsinden daha çok yer verdiği görülmüştür.

\subsubsection{Deyimler}

Romandan ulaşılan 582 deyim yazarın eserdeki deyim kullanma sıklı̆̆ı ile bu alanda sahip olduğu birikimini ve yeteneğini ortaya koymaktadır. En önemlisi anlatımdaki gücünü göstermektedir.

Yazarın, olayların anlatımı sırasında sıklıkla başvurduğu deyimler; aklına gelmek "hatırlamak", aklında tutmak "unutmamak, bellemek", aklından geçmek "düşünmek, esap almak "gözden geçirmek, incelemek, dikkate almak", geeri dönmek "geldiği yere tekrar gitmek”, gözlerini büültmek "1. genellikle kişinin öfkesini belli etmek için yaptığı hareket 2. şaşkınlığını belli etmek”, gözlerini yummak "gözlerini kapamak", gözünü atmak "birine veya bir şeye doğru bakmak", gün duumak "gün doğmak, sabah olmak", laf gitmek "birisi ya da bir şey üzerine konuşulmak", lafi ilerletmek "söze

\footnotetext{
19 Gagauz Türkçesinde "sahip, patron” anlamında kullanılan çorbacı sözcüğü aynı anlamıyla Batı Trakya Gümülcine ağzında kullanılmaktadır (TAS: 263).

20 Gagauz Türkçesinde düzen sözcüğünün “dokuma tezgâhı” anlamındaki kullanımına Türkiye Türkçesi ağızlarında rastlanılmaktadır (TAS: 345 ; DS: 1644).

Gagauz Türkçesinde "koşuşmak, bir iş için koşturmak, uğraşmak" anlamında karşımıza çıkan kaçın- fiilinin, Edirne ili ağızları ile Deliorman Türk ağızlarında da bu anlamıyla kullanıldığı görülmektedir (TAS: 560).

${ }_{22}$ ağıları ile Deliorman Türk ağızlarında da bu anlamıyla kullanıldığı görülm
} 
devam etmek” olarak belirlenmiştir. Romanda, esap almak deyimiyle çok sık karşılaşılmıştır. Bu deyim, 32 tekrar sayısıyla tüm deyimler içerisinde en fazla kullanılan deyim olmuştur.

Yazarın romanında kullandı̆̆ı deyimlerin büyük bir çoğunluğu Türkiye Türkçesi deyimleriyle benzer veya yakındır. Geriye kalan kısmı ise Türkiye Türkçesinde örneği bulunmayan Gagauz sahasına mahsus sayabileceğimiz deyimlerdir.

Öncelikle, Türkiye Türkçesiyle benzerlik veya yakınlık gösteren deyimler meydana geldiği unsurlar bakımından şu başlıklar altında ele alınabilir:

\section{a) Unsurları aynı olan deyimler:}

Bu başlık altındaki deyimler, Türkiye Türkçesindeki şekliyle biçim ve anlam bakımından özdeş olanlar ve fonetik açıdan farklı olanlar şeklinde iki tiptir. İkinci şekilde deyimi oluşturan unsurlar her ne kadar aynı olsa da bu unsurların birinde veya ikisinde fonetik açıdan farklılıklar mevcuttur. Bu şekilde olan deyimler arasında da gözlendiği kadarıyla anlam bakımından herhangi bir ayrım yoktur. Deyimlerin Türkiye Türkçesindeki şekline sadece fonetik açıdan farklı olanlar bölümünde yer verilmiştir.

Biçim ve anlam bakımından özdeş olan deyimler: akıl hocası "birine bir konuda yol göstermek, ne yapılacağını öğretmek”, akl başında akıllıca, doğru düzgün, akıllı başlı davranışlar gösteren kimse", dili dolaşmak "sarhoşluk, heyecan, utangaçlık, korku vb. sebeplerden dolayı söylemek istediği şeyi bir türlü söyleyememek", el etmek "uzaktan birine el sallamak", elinden gelmek "sözü edilen işi yapma becerisine sahip olmak", göz boyamak "kandırmak", kalın kafalı "bir şeyi geç anlayan, anlamakta güçlük yaşayan telakkisi kıt kimse", kendini kaybetmek "bayılmak", lafa karışmak birileri konuşurken araya bir başkası girerek konuşmaya katılmak”, önünü almak bir şeyi önlemek”, sözü geçmek "sözü dinlenmek, hatırı sayılmak", tersi dönmek şaşırarak nerede olduğunu anlayamamak, gideceği tarafı kestirememek", toz kondurmamak "bir şeyi kusursuz görmek veya öyle göstermek", tuz-buz olmak "paramparça olmak, kırılmak, tamir edilemeyecek biçimde kırılmak, küȩük parçalara ayrılmak", uykuya dalmak "uyumaya başlamak"

Fonetik açıdan farklı olan deyimler: GT aazının dadını bilmek "ağzının tadını bilmek, güzel, iyi yiyeceklerden anlamak" / TT ağzının tadını bilmek; GT ayaana çabuk "hızlı hareket eden kimseleri ifade etmek için kullanılır" / TT ayağına çabuk; GT allaa biler "Allah bilir, "belli değil" manasında söylenen bir söz” / TT allah bilir; GT benizi atmak "yüzünün rengi birdenbire sararmak, solmak" / TT benzi atmak; GT cöplerini doldurmak "ergonomik durumdan istifade ederek bol kazanç elde etmek" / TT cebini veya ceplerini doldurmak; GT dadı damaanda kalmak "yenilen veyahut içilen bir şeyin lezzetini unutamamak" / TT tadı damağında kalmak; GT eli ayaa tutmak "beden gücü iyi durumda olmak" / TT eli ayağı tutmak; GT kabaatı (birine ya da bir şeye) atmak "suçu bir kimsenin üzerine atmak" / TT kabahati (birine veya bir şeye) yüklemek; GT kulaa çalınmak "bir söz ya da haber başkasına söylenirken kendisi de duymuş olmak" / TT kulağına çalınmak; GT üreeni açmak "içini dökmek, derdini anlatmak, kalbini açmak" / TT yüreğini açmak; GT zeet çekmek "eziyet çekmek, güçlüğe ve sıkıntıya katlanma" / TT eziyet çekmek vb.

\section{b) Unsurları farklı olan deyimler:}

$\mathrm{Bu}$ başlığa dâhil olan deyimlerde genellikle bir veya birden fazla isim unsurunun Türkiye Türkçesindeki örneğinden farklı bir sözcükle ifade edildiği görülmektedir. Bu farklılık, zaman zaman bir sözcüğün yerine eş anlamlısının kullanılmasından ileri gelir. Örneğin; Türkiye Türkçesinde kalp ve 
baş sözcükleri kullanılarak teşkil edilen bazı deyimler Gagauz Türkçesinde ürek ve kafa ${ }^{23}$ sözcükleriyle kurulmuştur. Yine Gagauz Türkçesi ile Türkiye Türkçesi arasındaki birtakım kelimelerde yaşanan anlam farklılıkları da deyimleri oluşturan unsurların farklı olmasına yol açmıştır. Buna fikirdän geçirmek ve işitmezdän gelmek deyimleri misal gösterilebilir. Gagauz Türkçesinde fikir sözcügü "düşünce" anlamı yanında daha çok "akıl" anlamına sahiptir. işit- fiiliyle ilgili açıklamaya çalışmanın fiiller bölümünde yer verilmiştir. Ayrıca alttaki deyimler içerisinde fiil unsurlarının farklılaştı̆̆ iki örneğe rastlanılmıştır. (suuk kapmak, zaamet dökülmek, şamata kaldırmak).

GT fikirdän geçirmek "düşünmek" / TT aklndan geçirmek; GT fikirinä uymak "bir işi başkasının düşüncesine göre yapmak ve davranmak" / TT aklına uymak; GT işitmezdän gelmek "duymazlıktan gelmek, duymamış gibi yapmak" / TT duymazlıktan gelmek; GT kafasına gün geçmek "güneş çarpmak, sıcak havada uzun süre güneş altında kalmak” / TT başına güneş geçmek; GT sesä getirmek "dile getirmek, söylemek, anlatmak" / TT dile getirmek; GT suuk kapmak "soğuk almak, üşüterek hasta olmak" / TT soğuk almak, GT şamata kaldırmak "gürültü çıkarmak, ses yapmak" / TT şamata etmek; GT üreenä görä "gönlüne, isteğine göre" / TT kalbine göre; GT üreeni karmak "yanlış bir davranış ya da sözle birinin kalbini kırmak" / TT kalbini kırmak; GT zaamet dökülmek "zahmet etmek, zahmete katlanmak" / TT zahmet etmek.

Kimi deyimler ise Gagauz Türkçesinde bir ya da birden çok sözcüğü eksiltilmiş biçimiyle kullanılmaktadır. GT yaraya tuz ekelemek "acısını arttıracak bir eylemde bulunmak" / TT yaraya tuz biber ekmek; GT etleri tikennenmek "korkma sonucu vücuttaki kılların kabarması" / TT tüyleri diken diken olmak.

\section{Yukarıdaki iki başlıktan bağımsız olarak Türkiye Türkçesinde bulunmayan Gagauz Türkçesine mahsus diyebileceğimiz deyimler şöyledir:}

aazına kaşık uydurmak "birini memnun etmeye çalışmak", aldamaç dökmek "ziyafet vermek, misafirleri yemeklerle ağırlamak", bilmezeyä raslamak "bir şeyi anlamak, nolduğunu tahmin etmek", canında ilkyazı uyandırmak "bir kişinin mutlu olmasını sağlamak, sevindirmek", çukura kaymak "(iş açısından) durum kötüye gitmek, gerilemeye başlamak", darsıklık sarmak "hüzün, keder çökmek, hüzünlenmek", dizlerinä düşmek "birine yalvarmak", eşil saymak "bir kimseyi henüz olgunlaşmamış saymak", evallaa gelmek "özür dilemeye gitmek", gülmee almak "alaya almak", gün sırıtmak "güneş doğmak", kendini ahmaa çıkarmak "anlamamış gibi yapmak, anlamazlıktan gelmek, aptal gibi davranmak", kürkü tersine çevirmek "birine sert davranmaya başlamak" yorganı kendinä çekmek "karışıklıktan faydalanarak bir şeyi kendi yararına kullanmaya çalışmak", üreenä damnamak "bir şeyi anlamak, kalple hissetmek, şüphelenmek”

\subsubsection{Atasözleri}

Yazar, romanında bir duruma veya olaya uygun atasözü söylemeyi ihmal etmemiş, ara sıra bu sözlü edebiyat ürününe de başvurmuştur. Romanın bazı yerlerinde atasözü söylemeden önce "boşa dememişler, nica söleniler” şeklinde ifadeler kullandığı göze çarpmıştır.

Eserden 6 atasözü tespit edilmiştir. Tespit edilen bu atasözü örneklerinden birisinin Türkiye Türkçesindeki şekliyle birebir örtüştüğü görülür. Diğer dört atasözü başka sözcüklerle genişletilmiş

23 Bu durum Gagauz Türkçesinde "baş" yerine "kafa" sözcüğünün daha fazla kullanılmasına bağlanabilir. Romanda baş sözcügünün 19 defa, kafa sözcügünün 50 defa tekrarlanmış olması Gagauzların hangi sözcüğü daha çok kullanmayı tercih ettiklerini göstermesi açısından önemlidir. 
veya bazı sözcükleri çıkartılarak eksiltilmiş biçimlerdir. Ayrıca birinci ve ikinci atasözlerini meydana getiren unsurlardan kimisinin belli başlı sebeplerden ötürü farklılaştı̆̆ı gözlenmektedir.

GT Balık başından bozulmaa çekeder. / TT Balık baştan kokar. ; GT İildilmiş kafayı kılıç kesmez. / TT Eğilen baş kesilmez. ; GT Karıların saçları uzun, da fikiri kısa. / TT ; GT Neredä çokluk, orada bokluk. / TT Nerede çokluk orada bokluk. ; GT Su küçüünmüş. / TT Su küçüğün söz (sofra) büyüğün.

"Düün düünü ulaştırarmış" atasözünün ise hem Türkiye Türkçesinde hem de elimizdeki Gagauz atasözleri arasında örneğine rastlanmamıştır.

\section{5•3. İkilemeler}

Yazar, deyimlerden sonra romanında en çok ikilemeleri kullanmıştır. İfadeye güç katan bu tekrar öbeğinin romandan toplam 83 örneğine ulaşılmıştır. Farklı biçimlerde oluşturulmuş bu ikilemeler anlam bakımından incelendiğinde bunların aynı, zıt, eş ve yakın sözcüklerin yanı sıra biri anlamlı diğeri anlamsız veya ikisi de anlamsız sözcüklerin yinelenmesiyle kurulduğu görülmüştür: kesnikkesnik "kesik kesik, aralıklı", buunuk buunuk "boğunuk, boğunuk", çok-çok "uzun-uzun" dik-dik "ters ters”, gün-ömür "gün ömür”, saa-selem "sağ salim, zarar görmeden”, ileri-geeri “ileri geri”, yalan-falş "yalan yanlış", can-cun "herhangi bir kimse", satta patta "sat pat, orada burada, bazı yerlerde" vb.

İkilemeler anlamca olduğu gibi yapıca da farklılık gösterir. Eldeki ikilemeler arasında türlü yapım, hâl ve fiilimsi eklerini almış unsurlarla kurulu örneklere rast gelinmiştir. Bunlar sırasıyla şu şekildedir: birär-ikişär "birer ikişer", bölük-bölük "parça parça, dizi dizi"; bitki-bitkiyä "eninde sonunda", uzun uzadaya "uzun uzadıya, uzatarak", gün-gündän "günden güne", baştan ayaa "baştan aşağı", evdän evä "evden eve", primejdiyadan primejdiyaya "tehlikeden tehlikeye", orayz-burayz24 "oraya buraya"; diïyär-diimäz "değer değmez", dinnenä-dinnenä "dinlene dinlene”, durup-durup "bekleyerek, durarak", sarsalaya-sarsalaya "sarsa sarsa”, girän-çıkan "giren çıkan” vb.

ap-açık "apaçık", bom-boz "çok boz", kos-koca "koskoca" şeklindeki ikilemeler pekiştirme harfleri (m, p, s) kullanılarak elde edilmiştir. Çekimli iki ayrı fiilin yan yana getirilmesiyle oluşturulmuş bir ikileme örneği saptanmıştır: çlk-gez "çık gez".

\subsubsection{Kalıp sözler}

Romandan günlük iletişimde farklı maksatlarla kullanımına sıklıkla başvurulan kalıp söz örneklerine de ulaşılmıştır. Yazar, kahramanlar arasında kurduğu diyaloglarda kullandığı kalıp sözler ile insan ilişkilerine, bu ilişkilerde önem verilen belli başlı noktalara ve içinde yaşanılan kültüre bir ayna tutmuştur. Yazarın romanda bireyler arası ilişkilerin düzenlenmesinde ve hatta pekiştirilmesinde yardımcı olan kalıp sözleri kullandığı görülmüş̧ür.

Belirli durum, yer ve zamanlarda söylemeyi alışkanlık hâline getirdiğimiz kalıp sözlerin eserde karşlaşılan örnekleri Türkiye Türkçesindekilerle son derece benzerdir. Bu kalıp sözler işlevleri açısından aşağıdaki gibi gruplandırılabilir:

24 Bu ikilemenin aslındaki +a yönelme hâli ekinin +1 belirtme hâli ekine dönüşmesi "y" sesinin daraltıcı etkisine bağlanmaktadır. Hâl ekleri arasında meydana gelen işlev değişikliği Gagauz Türkçesinde çok sık rastlanan bir olaydır (Özkan, 1996: 125). 
İyi temenni sözleri: avşam hayır olsun, bereketli olsun "afiyet olsun", saalıklan kullan, kolay gelsin, allaa korusun.

Tebrik ve takdir sözleri: aferim, bravo, kutluca olsun, kutlu olsun.

Davet sözleri: buyur, buyurun.

Bağışlanma ifade eden sözler: allaah hepsimizi prost etsin "allah hepsimizi affetsin, bağışlasın"

Minnettarlık ve hoşnutluk ifade eden sözler: alla raazı olsun, saa ol (un), şükür, şükür allaha.

Üzüntü ve kınama bildiren sözler: yazık, ne yazık.

\section{Sonuç}

Bu çalışmada Mariya Mercanka’nın Kadem Kaynaa romanı söz varlığı açısından tahlil edilmiştir. Roman üzerinde yapılan tahlil sonucu saptanan söz varlığı ögelerinden hareketle yazarın dili ve üslubu hakkında bazı çıkarımlarda bulunulmuştur. Ayrıca bu ögelerin Gagauz Türkçesinin genel söz varlığıyla durumuna bakılmış, Türkiye Türkçesiyle arasındaki benzerlik ve farklılıklara değinilmiştir.

Çalışmada öncelikle isim ve fiil türünden sözcükler değerlendirilmiştir. Bu kısımlarda yazarın romanda sık bir biçimde kullandığı sözcüklere yer verilmiştir. Roman boyunca en çok tekrarlanan 82 isim ve 49 fiil belirlenmiştir. Belirlenen bu sözcükler arasında da yazarın belli başlı isimler ile fiilleri daha çok yinelediği görülmüştür. Özellikle isimler kategorisinde bulunan sözcükler ve bunların sayıca fiillerden fazla oluşu romanın içeriğiyle beraber romanda öne çıkarılmak istenen noktaların anlaşılmasına olanak vermiştir. Söz gelimi; kolhoz, kolhoz başı, predsedetal, çorbacı gibi sözcükler romandaki olayların yaşandığı döneme, yasla, uşak, çocuk, uşak başçası gibi sözcükler ise romanın temasına çağrışım yapmaktadır. Bunun yanı sıra Mariya Mercanka'nın romanında Gagauz Türklerinin sosyal hayatını ve kültürünü yansıtan sözcükleri sık sık tekrarlamış olması dikkat çekmektedir. Buna yukarıda değinilen at, beygir, yortu vb. daha birçok sözcük örnek teşkil etmektedir.

Mariya Mercanka, romanında halk kültürüne geniş bir şekilde yer vermiştir. Köy halkının belirli zamanlarda sırasıyla kutladığı çeşitli yortulara, yortular özelinde gerçekleştirdiği âdetlere ve birtakım inanışlara değinerek aslında bunların Gagauzların gündelik yaşamının ayrılmaz ve önemli bir parçası olduğunu vurgulamak istemiştir. Romandaki bazı sözcükler de bu duruma bağlı olarak daha sık tekrarlanmıştır.

Roman üzerindeki incelemeler sırasında eş veya yakın anlamlı sözcüklerin Türkçe olanlarından başka Rusça veya başka bir yabancı dilden alıntı şekline de rastlanmıştır. Böyle olanlarda bazen alıntı sözcügün daha fazla yinelenmesi dile bu kullanımın yerleşmesine bağlanabileceği gibi yazarın tercihi olarak da açıklanabilir. (tablodan yasla, uşak başçası sözcükleri; roman içerisinden okul, şkola sözcükleri örnektir). Elbette bunun tam tersi örnekler de vardır. Örneğin; isimler tablosunda "toplantı" anlamına gelen Türkçe kökenli oturuş sözcüğünün 15 kez yinelendiği görülür. Fakat aynı anlamdaki Rusça zasedanie/zasedaniy sözcükleri romanda birer kez geçmiştir.

Mariya Mercanka'nın eserinde kullandığı dili değerlendirecek olursak; romanda Türkçe kökenli sözcüklerin yanı sıra Arapça, Farsça, Rusça, Rumence, Bulgarca ve Yunancadan alıntı sözcüklerle de karşılaşılmıştır. Ancak alıntıların bir kısmının Türkçe ek ve köklerin ilavesiyle Türkçeleştirilirmiş 
biçimler olduğu görülmüştür. Bu tip örneklere çalışmadaki fiiller başlığı altında daha çok denk gelinmiştir (fidancık, kolhoz başı, peydalan-, prost et-, zeetle- vb.). Tablolar içerisinde Gagauz Türkçesine has kullanımlar olarak belirlediğimiz saurgun, oturuş, önderci ve yaan- sözcükleri Türkçe kökenlidir. Ayrıca gerek tablolara gerekse çalışma içerisindeki diğer başlıklara dâhil olan sözcüklerin çoğunlukla Türkiye Türkçesiyle ortak olduğu görülür. Ortak sözcüklerden bazısının Gagauz Türkçesinde şeklen uğradığı değişiklik ilk gözlenenler arasındadır. Romanda, Rusçadan alıntı sözcüklerin diğerlerine oranla daha fazla yer kapladığı ve bu dilden alıntıların hayatın çoğu alanında aktif bir şekilde kullanıldığı gözlenir. Yazar; siyasi, idari, teknik, bilim, eğitim, meslek kolları ve sanatla ilgili alanlarda Rusça terim ve sözcüklere daha çok başvurmuştur. Bölgedeki resmî dillerden biri olan Rusçanın eğitim başta olmak üzere devlet kurumlarında yaygın bir şekilde kullanılması söz konusu alanlarda Rus dilinden alıntıların artmasına yol açmıştır. Ayrıca kentte iletişim dili olarak çoğunlukla Rusçanın kullanılması da yazarın diline etki etmiştir.

Mariya Mercanka’nın romanında karşılaşılan Arapça, Farsça ve Yunanca alıntı sözcüklerin önemli bir kısmı fonetik bakımından Türkiye Türkçesi ağızlarıyla ortaktır. Özellikle Arapça ve Farsça kökenli sözcüklerin neredeyse çoğu bu yönüyle STT'den ayrılır. (Yun. laana GT < laana TAS; Yun. popaz GT < popaz TAS, DS; Fa. afta GT < afta TAS; Ar. daul GT < daul TAS; Ar. cendem GT < cendem TAS vb.). Romandaki Bulgarca ve Rumence kökenli sözcük sayısı ise sınırlıdır.

Romanda Türkiye Türkçesi ağızlarıyla benzer olduğu görülen çok sayıda sözcük ayrıca ele alınmalıdır. Bunların türlü yönlerden (fonetik, morfolojik, semantik) karşllaştırmalı bir şekilde incelenmesi Gagauzların dili ve tarihiyle ilgili hususlara açıklık getirilmesi veyahut var olanların yeni örneklerle desteklenmesi açısından önemlidir. Her ne kadar bu çalışmada sözcüklere hangi bölge ağızlarında rastlanıldığı ayrıntılı bir biçimde belirtilmemiş olsa da tespitler esnasında bazı kullanımların Deliorman ve Kuzey Trakya Türk ağızlarıyla örtüşmesi dikkati çekmiştir.

Kadem Kaynaa romanındaki söz varlığının bir kısmı atasözü, deyim, ikileme ve kalıp sözlerden oluşur. Romandan ulaşlan atasözü hariç deyim, ikileme ve kalıp söz miktarının azımsanmayacak ölçüde olması yazarın anlatımdaki zenginliğini ve gücünü ortaya koyar.

Mariya Mercanka'nın geçmişten gelen kültürel birikimlerini romanına kattığı görülür. Çalışmanın başında dikkatlere sunulan genel söz varlığı tablosuna göre Kadem Kaynaa romanı nicelik bakımından zengin bir deyim varlığı sergilemiştir. Romanda, az sayıda da olsa atasözlerine de yer verilmiştir. Gagauzların sözlü edebiyat döneminin yakın bir zamana dek sürmesi hâliyle, şair ve yazarların daha sonra oluş̧turdukları edebî türdeki eserlere yansımıştır. Sözlü kültür ortamında yetişen yazarlardan biri olan Mariya Mercanka da bu alandaki deneyimlerini romanına taşımıştır. Yazarın, eserinde sözlü edebiyat ürünlerinden deyimleri geniş ölçüde kullanmasında deyimlerin, biçim ve anlam gibi özellikler bakımından birçok bağlamda kullanılmaya daha elverişli dilsel yapılar olması da etkili olmuştur.

Kadem Kaynaa romanında kullanılan deyimlerin büyük bir kısmı çalışmada başvurulan sözlük ve kitaplardaki25 Gagauzca deyimler arasında yer almamaktadır: avariyaya düşmek "kazaya uğramak, kaza yapmak", bura gibi şişmek "hindi gibi kabarmak, büyüklük taslamak, morarmak", çukura kaymak, (kendini) gülüntü etmek "insanın kendini ya da başka bir kimseyi gülünç duruma düşürmesi, rezil ve maskara etmesi”, gün devirilmek "güneş batmaya başlamak, dönmek", kendini ahmaa

25 Nevzat Özkan’ın “Gagavuz Edebiyatı” kitabı ile Atanas Manov’un “Gagauzlar (Hıristiyan Türkler)” kitabındaki atasözü ve deyimlere bakılmıştır. 
çıkarmak, korku kapmak "1. endişeye kapılmak, kaygllanmak" 2. "korkmak", parayı sıkmak "çok harcama yapmamak ya da kontrollü harcama yapmak", sıkletä atmak "sıkıntı basmak, çok sıkılıp daralmak", takaza düşmek "birine kaba sözler söylemek, azarlamak", ürää gülmek "sevinçli, mutlu olmak", yalın kalkmak "alev, yangın çıkmak" gibi deyimler yazarın söz hazinesine ait deyim örnekleri olarak belirlenmiştir. Romandaki atasözlerinden ise kaynak kitaplarda bulunmayan üç örnek tespit edilmiştir. Bunlar; "Düün düünü ulaştırarmış", "Iildilmiş kafayı kılıç kesmez" ve "Su küçüünmüş" şeklindeki atasözleridir. Son atasözüne Türkiye Türkçesi atasözleri (Su küçüğün söz (sofra) büyügü̈n) arasında rastlanılır. Bu şekline göre, yazar atasözünü kısaltma yoluna giderek romanda sadece o anki duruma uyan kısmını söylemeyi tercih etmiştir.

Kaynaklarda yer alan Gagauz atasözlerinin bazısı romanda farklı biçimlerde karşımıza çıkmıştır. Bu farklılıklar da romandaki atasözlerinin Türkiye Türkçesindeki şekliyle karşılaştırıldığı bölümde belirtilen sebeplere dayanmaktadır. KK Balık başından bozulmaa çekeder. / GT Balık baştan kokar.; KK Karıların saçları uzun, da fikiri kısa. / GT Karının saçı uzundur aklı kısadır.; KK Neredä çokluk, orada bokluk. / GT Nerde çokluk orda bokluk.

Kadem Kaynaa romanı ikilemeler açısından da oldukça zengindir. İkilemeler, deyimlerden sonra romanda örneğine en çok denk gelinen söz öbeği olarak ikinci sırada yer almıştır. Anlam ve yapı bakımından incelenen bu ikilemelerden; birinci grupta aynı sözcüğün tekrarıyla kurulanlar, ikinci grupta hâl eki almış sözcüklerle kurulanlar çoğunluğu oluşturmuştur.

Çalışmada, romandaki kalıp sözler de incelemeye alınmıştır. İnceleme neticesinde romanda kullanılan kalıp söz örneklerinden ikisi hariç geriye kalanların olumlu duygu değerine sahip sözler olduğu görülmüştür.

Çalışmamızda romandan ortaya koyduğumuz ikileme ve kalıp söz örnekleri bu iki söz öbeğinin Gagauz Türkçesinde bulunan/kullanılan biçimlerine dair fikir vermiştir. Bununla alakalı olarak burada belirtmeyi gerekli gördüğümüz önemli bir husus vardır. Bu da Gagauz Türkçesi sahasında ikilemeler ile kalıp sözlerin ortaya çıkarılmasına yönelik çalışmalara duyulan ihtiyaçtır. İkileme ve kalıp söz varlığının derlenip müstakil bir çalışmada topluca sunulması her dil ve lehçe için olduğu gibi Gagauz Türkçesi için de elzemdir.

Çalışmadaki deyimler, atasözleri, ikilemeler ve kalıp sözler başlıkları altında Türkiye Türkçesiyle müşterek kullanımların yanı sıra yazarın söz varlığındaki farklı kullanımlar da gösterilmeye çalışılmıştır. Bunlar arasında atasözü ve deyimlerden Gagauz Türkçesiyle ilgili kaynaklara geçmemiş olanlar belirlenerek dile kazandırılmaları sağlanmıştır.

Buraya kadar verilen bulguları toparladığımızda; Mariya Mercanka, birtakım yabancı etkilerin dışında romanında sade ve akıcı bir dil kullanmıştır. Romanın genelinde büyük ölçüde Türkçe kökenli sözcükler kullanarak eserin açık ve anlaşılır bir üsluba sahip olmasını sağlamıştır. Öte yandan yazarın söz dağarcığında Türkiye Türkçesi ve ağızlarında kullanılan ortak pek çok sözcüğün bulunması romanın anlaşılırlığını arttırmıştır.

Yazar romanında atasözü, deyim, ikileme ve kalıp sözleri yerli yerinde ve ustalıkla kullanarak anlatımına canlılık ve renk katmıştır. Aynı zamanda bu söz kalıpları sayesinde eserin dilini günlük konuşma diline yaklaştırarak doğal ve çekici bir üslup yaratmıştır. 
Romandaki eş anlamlı sözcüklerin ve deyimlerin çeşitliliği ise yazarın dili kullanmadaki yetkinliğinin ve becerisinin bir göstergesidir. Bu şekilde anlatımını monotonluktan kurtaran yazar üslubuna hareket getirmiştir.

Mariya Mercanka'nın eserinde sıklıkla kullandığı sözcüklerin Gagauz halkının geçmiş yaşamından, kültüründen, inançlarından, gelenek ve göreneklerinden izler taşıdığı görülür. Yazar, gerek romanında yer verdiği atasözü, deyim ve kalıp sözlerle gerekse sözünü ettiği yortu ve âdetlerle Gagauz Türklerinin kültürel değerlerini en iyi şekilde yansıtmıştır. Bilgi mahiyeti taşıyan bu millî yortu ve âdetlerden ötürü yazarın roman içerisindeki üslubu kimi zaman didaktik bir hüviyet kazanmıştır.

Sonuç olarak; Kadem Kaynaa romanı, her şeyden önce Gagauz sahası için zengin bir dil ve kültür malzemesi durumundadır. Söz konusu eserin incelendiği bu çalışmayla yazarın dili ve üslubu açısından olduğu kadar Gagauz Türkçesi açısından da değerli kazanımlar elde edilmiştir.

\section{Kisaltmalar}

TT: Türkiye Türkçesi

GT: Gagauz Türkçesi

GTS: Gagauz Türkçesi Sözlüğü

TAS: Trakya Ağızları Sözlüğü

DS: Derleme Sözlüğü

STT: Standart Türkiye Türkçesi

KK: Kadem Kaynaa

\section{Kaynakça}

Ahmet Kelağa, İ. (2012). Yunanca El Sözlüğü. Ankara: Engin Yayınevi.

Aksoy, Ö. A. (2017). Atasözleri ve Deyimler Sözlüğü/Atasözleri Sözlüğü-1. İstanbul: İnkllâp Kitabevi.

Argunşah, M. ve Argunşah H. (2007). Gagauz Yazıları. Kayseri: Türk Ocakları Kayseri Şubesi.

Argunşah, M. (1996). Çağdaş Gagauz Şiiri. Türk Dili (Türkiye Dışı Çağdaş Türk Şïri Özel Sayısı), S. 531. 678-699.

Arnaut, T. ve Hünerli, B. (2017). Ukrayna Gagauzları. Tehlikedeki Diller Dergisi, C. 7, S. 11. 17-50.

Babaoğlu, N. (1999). Gagauz Türklerinin Kirillik Alfabesinden Lâtin Alfabesine Geçmesi. Türk Dünyası Dil ve Edebiyat Dergisi, S. 7. 56-59.

Bulgarca Cep Sözlüğ̈̈. (2016). İstanbul: Fono Yayınları.

Çimpoeş, L. (2018). Gagauzların İlkyaz Yortuları (Bayramları) Adetler ve Onlara Bağlı Folklorik Unsurlar, 9. Milletlerarası Türk Halk Kültürü Kongresi Bildirileri. Ankara: T.C. Kültür ve Turizm Bakanlığı Yayınları.

Derleme Sözlüğ ̈̈ (1993). C. II-XII. Ankara: Ankara Üniversitesi Basımevi.

Devellioğlu, F. (2010). Osmanlıca-Türkçe Ansiklopedik Lûgat. Ankara: Aydın Kitabevi.

Erdin, C. (2020). Mariya Mercanka’nın Kadem Kaynaa Adlı Romanının Söz Varlı̆̆ı Bakımından İncelenmesi (Yayımlanmamış Yüksek Lisans Tezi). Edirne: Trakya Üniversitesi Sosyal Bilimler Enstitüsü Balkan Çalışmaları Anabilim Dalı.

Gültek, V. (2004). Rusça-Türkçe Sözlük. Ankara: Bilim ve Sanat Yayınları.

Hacıeminoğlu, N. (2016). Türk Dilinde Yapı Bakımından Fïiller. İstanbul: Bilge Kültür Sanat. 
Hünerli, B. (2019). Mihail Çakir’in Gagauzca (Türkçe)-Rumence Sözlüğü (İnceleme- Metin). İstanbul: Paradigma Akademi.

Hünerli, B. (2019). Gagauz Atasözlerinde “At”, TÜR̈̈K Uluslararası Dil, Edebiyat ve Halkbilimi Araştırmaları Dergisi. Y. 7, S. 16. 108-116.

Kaynak, İ. ve Doğru A. M. (1991). Gagauz Türkçesinin Sözlüğü. Ankara: Kültür Bakanlığı Yayınları.

Kowalski, T. (1949). Kuzey-Doğu Bulgaristan Türkleri ve Türk Dili. (Çev. Ö. F. Akün). İstanbul Üniversitesi Edebiyat Fakültesi Türk Dili ve Edebiyatı Dergisi. C. 3, S. 2-3. 477-500.

Manov, A. (2001). Gagauzlar (Hiristiyan Türkler). (Bulgarcadan çev. M. Türker Acaroğlu). Ankara: Türk Tarih Kurumu Basımevi.

Mercanka, M. (2017). Kadem Kaynaa. Chişinau: Pontos.

Özden, M., Doğan, L. ve Bayraktar, S. (2018). Trakya Ağızları Sözlüğü C. I-II. Edirne: Trakya Üniversitesi Matbaası, Yayın No: 192.

Özkan, N. (1996). Gagavuz Türkçesi Grameri. Ankara: Türk Dil Kurumu Yayınları.

Özkan, N. (2017). Gagavuz Edebiyatr. İstanbul: Bilge Kültür Sanat.

Özkan, N. (2018). "Gagavuz Türkçesinde Yabancı Unsurlar”. Gagauz Dili, Tarihi, Coğrafyası ve İnanç Sistemleri. (Ed. Selçuk Kırlı, Alev Sınar Uğurlu). Türk Ocakları Bursa Şubesi Yayınları: 14. 181190.

Pokrovskaya, L. A. (2017). Gagauzların Hristiyan Dinî Terminoloji Sistemindeki Müslümanlıkla İlgili Unsurlar. (Çev. Bülent Hünerli). Kesit Akademi Dergisi, Y. 3, S. 7. 421-427.

Pokrovskaya, L. A. (2018). Gagauzcadaki Diyalektlerin Kökeni Hakkında. (Çev. Bülent Hünerli). Uluslararası Türk Lehçe Araştırmaları Dergisi, C. 2, S. 2. 168-172.

Türk Dil Kurumu (1998). Türkçe Sözlük. 9. bs., Ankara: Türk Dil Kurumu Yayınları.

Zayonçkovski, V. (2018). Gagauzların Etnogenezine Dair. (Çev. Bülent Hünerli). Uluslararası Dil, Edebiyat ve Halkbilimi Araştırmaları Dergisi, Y. 6, S. 14. 261-267.

http://www.unesco.org/languages-atlas/index.php genel ağ sayfasından 5.05. 2020 tarihinde erişildi.

TDK, https://sozluk.gov.tr/ genel ă̆ sayfasından 15.05.2020 tarihinde erişildi. 